\title{
\#USGS
}

science for a changing world

\section{Volcanic Activity in Alaska and \\ Kamchatka: Summary of Events and \\ Response of the Alaska Volcano \\ Observatory}

By Robert G. McGimsey ${ }^{1}$ and Kristi L. Wallace ${ }^{1}$

Open-File Report 99-448

1999

AVO is a cooperative program of the U.S. Geological Survey, University of Alaska Fairbanks Geophysical Institute, and the Alaska Division of Geological and Geophysical Surveys. AVO is funded by the U.S. Geological Survey Volcano Hazards Program and the State of Alaska

This report is preliminary and has not been reviewed for conformity with U.S. Geological Survey editorial standards or with the North American Stratigraphic Code. Any use of trade, firm, or product names is for descriptive purposes only and does not imply endorsement by the U.S. Government.

\section{U.S. DEPARTMENT OF THE INTERIOR}

U.S. GEOLOGICAL SURVEY

${ }^{1}$ Alaska Volcano Observatory, 4200 University Dr., Anchorage, AK 99508-4664 


\section{CONTENTS}

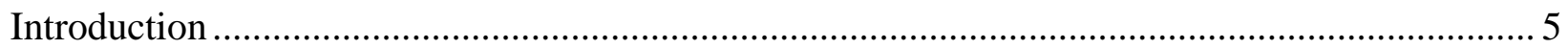

Reports of volcanic activity, northeast to southwest along Aleutian arc ……............................... 6

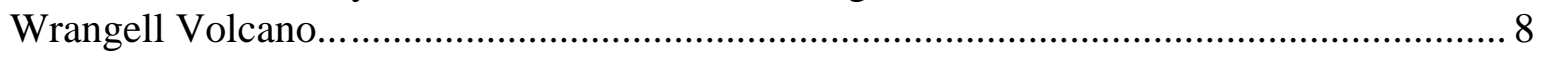

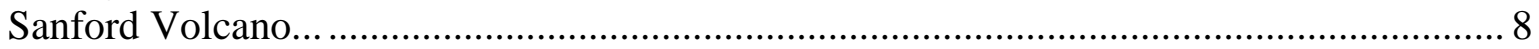

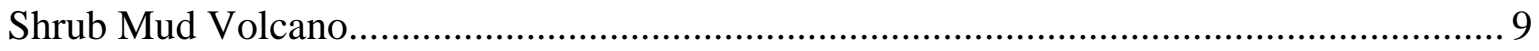

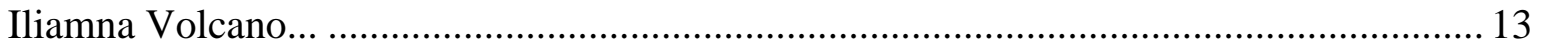

Katmai Group: Martin/Mageik/Snowy/Kukak ................................................................ 13

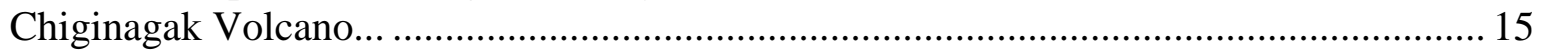

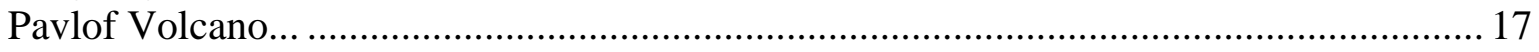

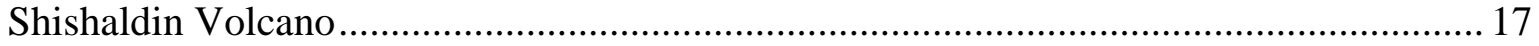

Okmok Volcano................................................................................................... 18

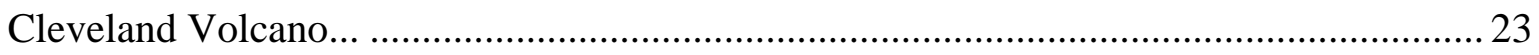

Amukta Volcano........................................................................................................ 24

Reports of volcanic activity, Kamchatka Peninsula, and the northern Kurile Islands, Russia ..... 25

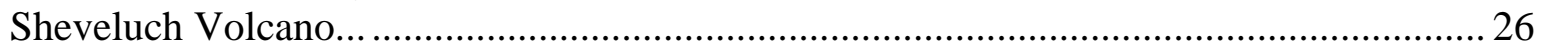

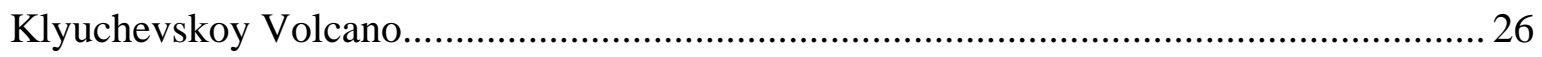

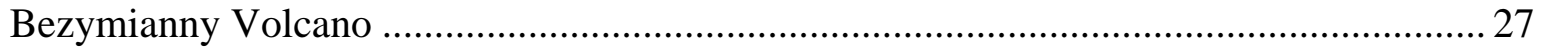

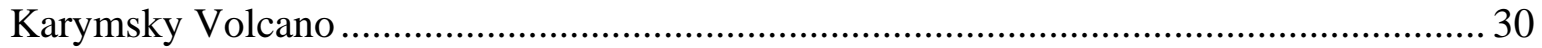

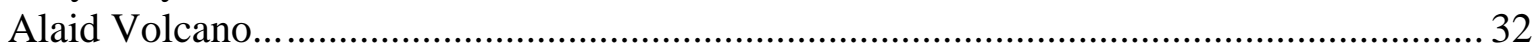

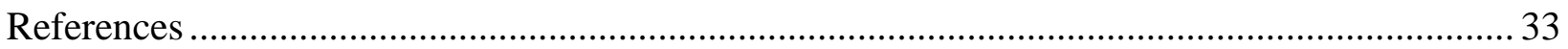

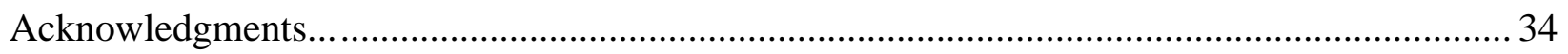

Figures:

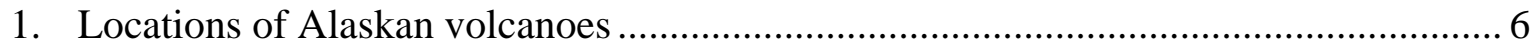

2. Locations of Alaskan volcanoes featured in this report ................................................ 7

3. Seismically monitored Alaskan volcanoes of 1997 .................................................... 7

4. Southwest face of Mount Sanford ……………….............................................. 9

5. Location map for Shrub and Klawasi mud volcanoes ................................................ 10

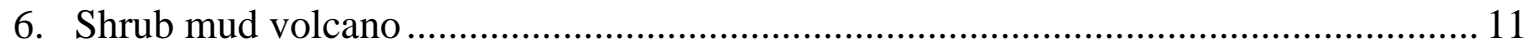

7. Map showing $\mathrm{CO}_{2}$ vents and mud deposits at Shrub mud volcano .............................. 11

8. Summit area of Shrub mud volcano ........................................................................ 12

9. Sketch map showing location of Snowy Mountain and Kukak volcano ....................... 15

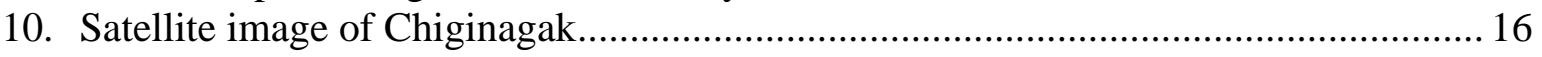

11. Satellite image of Okmok caldera showing 1997 lava flows ....................................... 19

12. Sketch map of Okmok caldera................................................................................ 20

13. Satellite image showing thermal anomaly at Okmok Volcano.....................................2 21

14. Composite photo showing lava flow from Cone A in Okmok caldera... ..................... 22

15. Satellite image showing thermal anomaly and plume at Okmok Volcano....................22

16. Location map for Russian volcanoes feature in this report......................................... 25

17. Satellite image of May 8, 1997, showing eruption cloud from Bezymianny............... 29

18. Satellite image of December 5, 1997, showing eruption cloud from Bezymianny...... 30

19. Photo showing lava flow on southwest flank of Karymsky volcano. ............................ 31 
Tables:

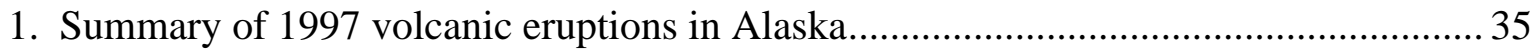

2. Summary of 1997 suspect volcanic events in Alaska ............................................ 36

3. Summary of 1997 volcanic activity on Kamchatka Peninsula and Kurile Islands........ 36

4. Level of Concern Color Code for volcanic activity ................................................ 37

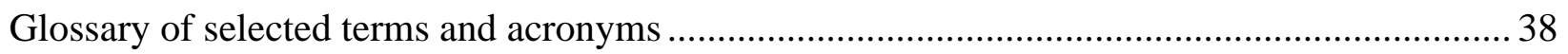

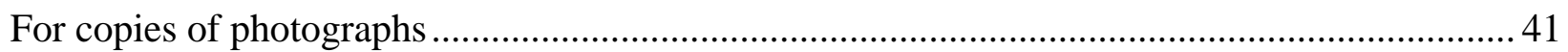

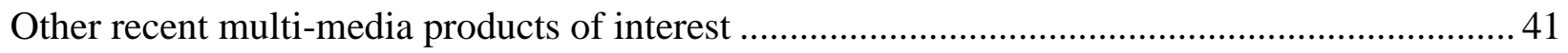

COVER PHOTO: Lava flows emanating from Cone A in Okmok caldera. Photo by John Sease, NOAA National Marine Mammals Laboratory, February 28, 1997. 


\section{INTRODUCTION}

The Alaska Volcano Observatory (AVO) monitors over 40 historically active volcanoes along the Aleutian Arc (fig. 1). Twenty are seismically monitored and for the rest, the AVO monitoring program relies mainly on pilot reports, observations of local residents and ship crews, and daily analysis of satellite images. In 1997, AVO responded to eruptive activity or suspect volcanic activity at 11 volcanic centers (fig. 2; tables 1,2): Wrangell, Sanford, Shrub mud volcano, Iliamna, the Katmai group (Martin, Mageik, Snowy, and Kukak volcanoes), Chiginagak, Pavlof, Shishaldin, Okmok, Cleveland, and Amukta. Of these, AVO has real-time, continuously recording seismic networks at Iliamna, the Katmai group, and Pavlof (fig. 3). The phrase "suspect volcanic activity" (SVA), used to characterize several responses, is an eruption report or report of unusual activity that is subsequently determined to be normal or enhanced fumarolic activity, weather-related phenomena, or a non-volcanic event.

In addition to responding to eruptive activity at Alaska volcanoes, AVO also disseminated information for the Kamchatkan Volcanic Eruption Response Team (KVERT) about the 1997 activity of 5 Russian volcanoes--Sheveluch, Klyuchevskoy, Bezymianny, Karymsky, and Alaid (SVA)(fig. 16; table 3).

This report summarizes volcanic activity and SVA in Alaska during 1997 and the AVO response, as well as information on the reported activity at the Russian volcanoes. Only those reports or inquiries that resulted in a "significant" investment of staff time and energy (here defined as several hours or more for reaction, tracking, and follow-up) are included. AVO typically receives dozens of reports throughout the year of steaming, unusual cloud sightings, or eruption rumors. Most of these are resolved quickly and are not tabulated here as part of the 1997 response record.

Descriptions of volcanic activity and AVO responses are presented in geographical order from northeast to southwest along the Aleutian volcanic arc. All elevations reported are above sea level (ASL) unless noted, and time is reported as Alaska Standard Time (AST), Alaska Daylight Time (ADT), or Kamchatkan Standard Time (KST), Kamchatkan Daylight Time (KDT) (see glossary). A summary of volcanic activity is presented in Table 1. SVA that required a significant response are summarized in Table 2 . Table 3 summarizes volcanic activity and responses in Kamchatka and the northern Kurile Islands. Information on 1997 responses is compiled from AVO weekly updates and information releases, the AVO 1997 "Chron book"--a chronological collection of daily or weekly staff notes for a particular year--and the Smithsonian Institution Global Volcanism Network Bulletin (GVN), which uses AVO as the source for reports on Alaska volcanoes.

AVO response to reported remote volcanic activity varies depending on the source and content of the observation. After receiving a report and possibly conducting follow-up investigation of the factual information, AVO usually contacts the National Weather Service (NWS) and Federal Aviation Administration (FAA) for corroboration and/or formal notification. For a verified, significant eruption, an established call-down procedure to formally notify other government agencies, air carriers, facilities at risk, and the media is initiated. If an eruption is not confirmed, a notation is made in the AVO Chron book and no further action is taken. A special information release may be distributed if eruptive activity is confirmed, and the events are further summarized in the AVO weekly update distributed each Friday via electronic mail and facsimile. 


\section{VOLCANIC ACTIVITY, NORTHEAST TO SOUTHWEST ALONG ALEUTIAN ARC}

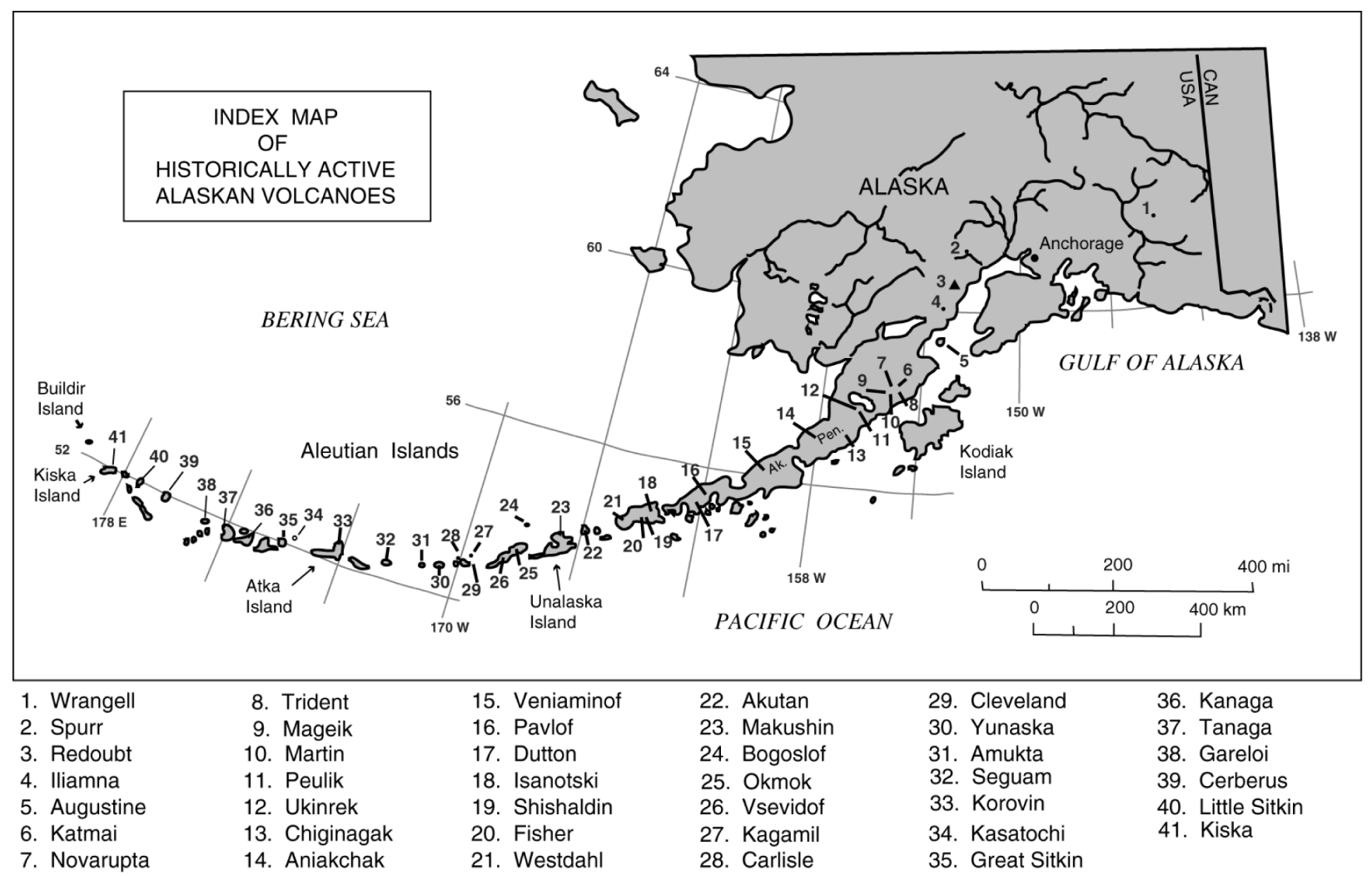

Figure 1. Location (triangles) of historically active volcanoes in Alaska (Miller and others, 1998). 


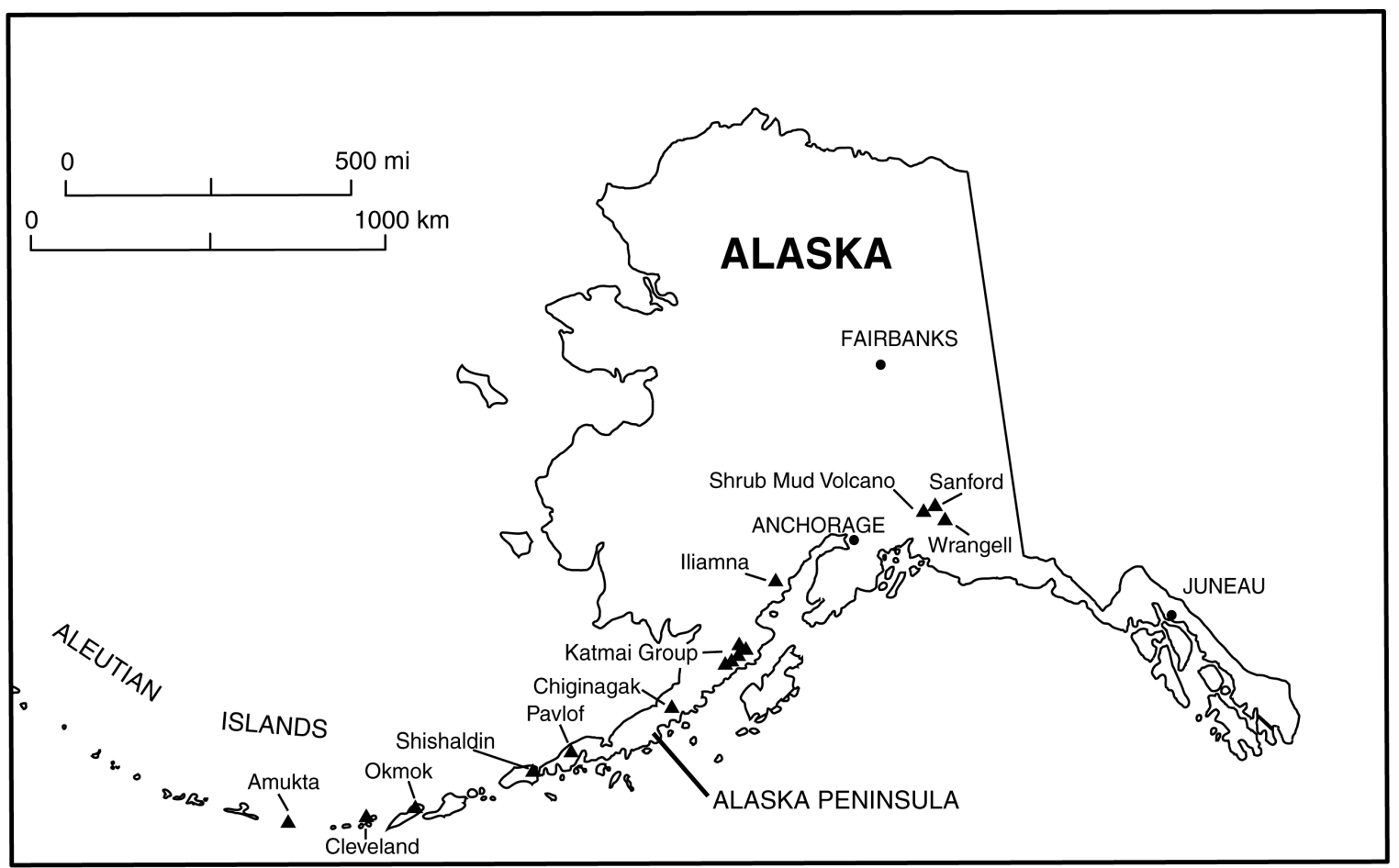

Figure 2. Location (triangles) of Alaskan volcanoes mentioned in this report

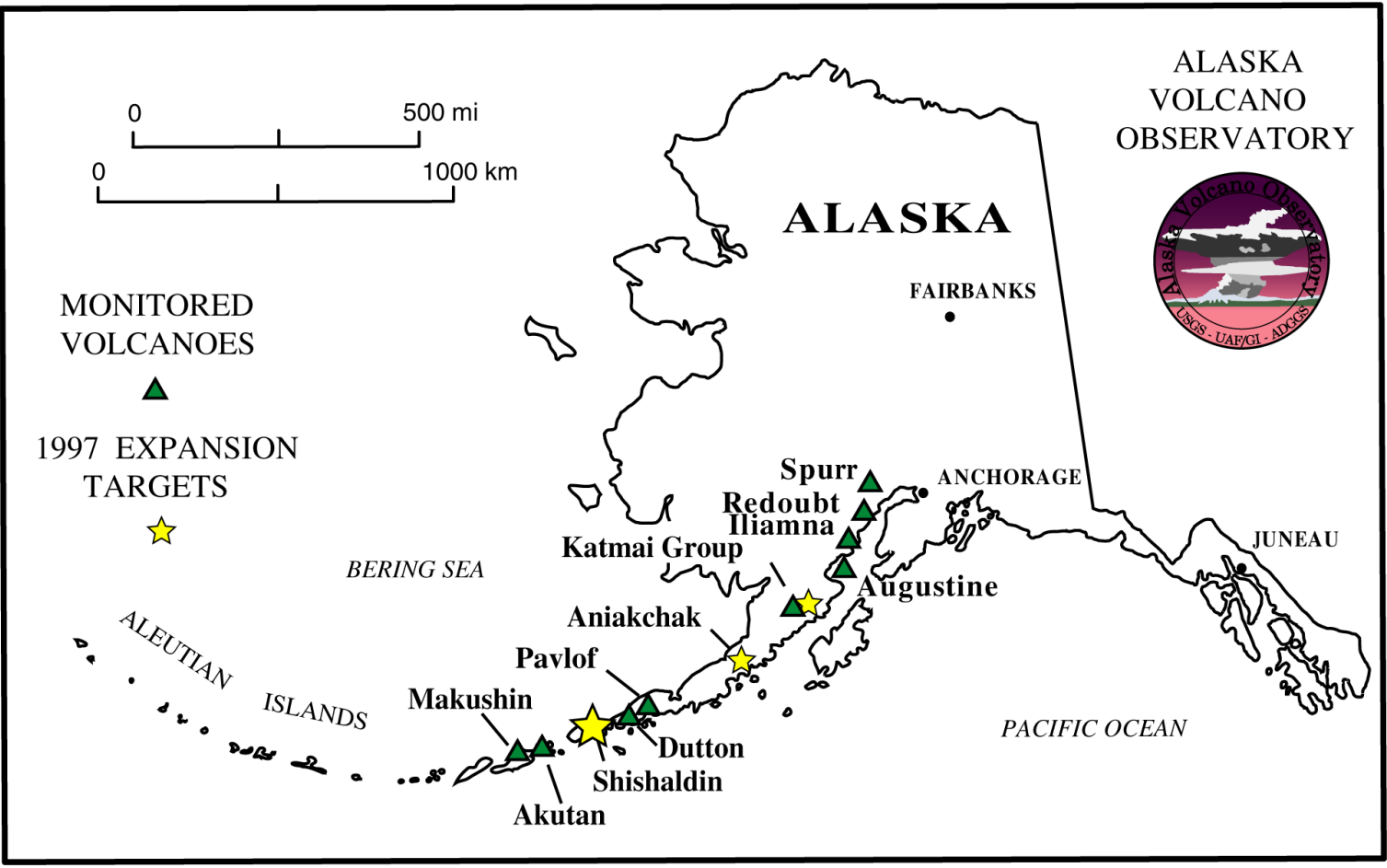

Figure 3. Seismically monitored Alaskan volcanoes as of 1997. The Katmai group is a closely spaced group of young volcanic centers and includes Griggs, Katmai, Novarupta, Trident, Mageik, Martin, Snowy and Kukak volcanoes. 


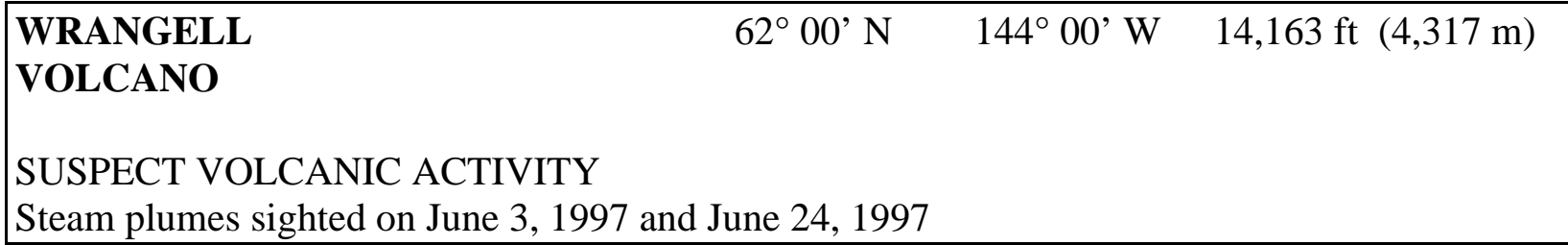

Mount Wrangell is a large, glacier-covered shield volcano in the Wrangell-St. Elias National Park of eastern Alaska. The summit caldera is ice-filled and rimmed by three small geothermally active craters, which historically have been the source of intermittent steam venting.

On June 3, 1997, AVO received a pilot report of steam rising from the summit of Wrangell Volcano. Three weeks later, on June 24, another report described a steam plume rising up to 700 $\mathrm{ft}(\sim 213 \mathrm{~m})$ above the summit. No sign of activity was observed on satellite imagery and no mention was made in the AVO weekly update. Several active fumaroles in the summit caldera frequently produce steam plumes that are mistaken for eruptive activity (Nye, 1991; Richter and others, 1995; Neal and McGimsey, 1997). AVO relies on local observers, pilots, and satellite imagery for information due to lack of any real-time monitoring equipment on the volcano. Except for a vigorous steam and ash emission in 1902, no documented historical eruptions have occurred at Wrangell Volcano.

\begin{tabular}{|c|c|c|c|}
\hline MT. SANFORD & $62^{\circ} 40^{\prime} \mathrm{N}$ & $144^{\circ} 07^{\prime} \mathrm{W}$ & $16,237 \mathrm{ft}(4,949 \mathrm{~m})$ \\
\hline
\end{tabular}

Mount Sanford is a snow and ice-covered Pleistocene shield volcano in the Wrangell volcanic field. The southwest face is a shear wall with vertical relief of 8,000 ft ( 2,400 m) (fig. 4), and is the site of almost constant rock-, snow-, and ice-falls, activity which on occasion is energetic enough to produce anomalous steam plumes (Neal and others, 1995; 1996).

A Copper Center resident reported a large steam cloud rising from the southwest face of Mt. Sanford on September 30, 1997. The cloud persisted throughout the afternoon before dissipating. Based on previous similar activity, AVO staff concluded that the cloud resulted from avalanching or debris fall from the southwest face. AVO does not have seismic networks in the Wrangell volcanic field. 


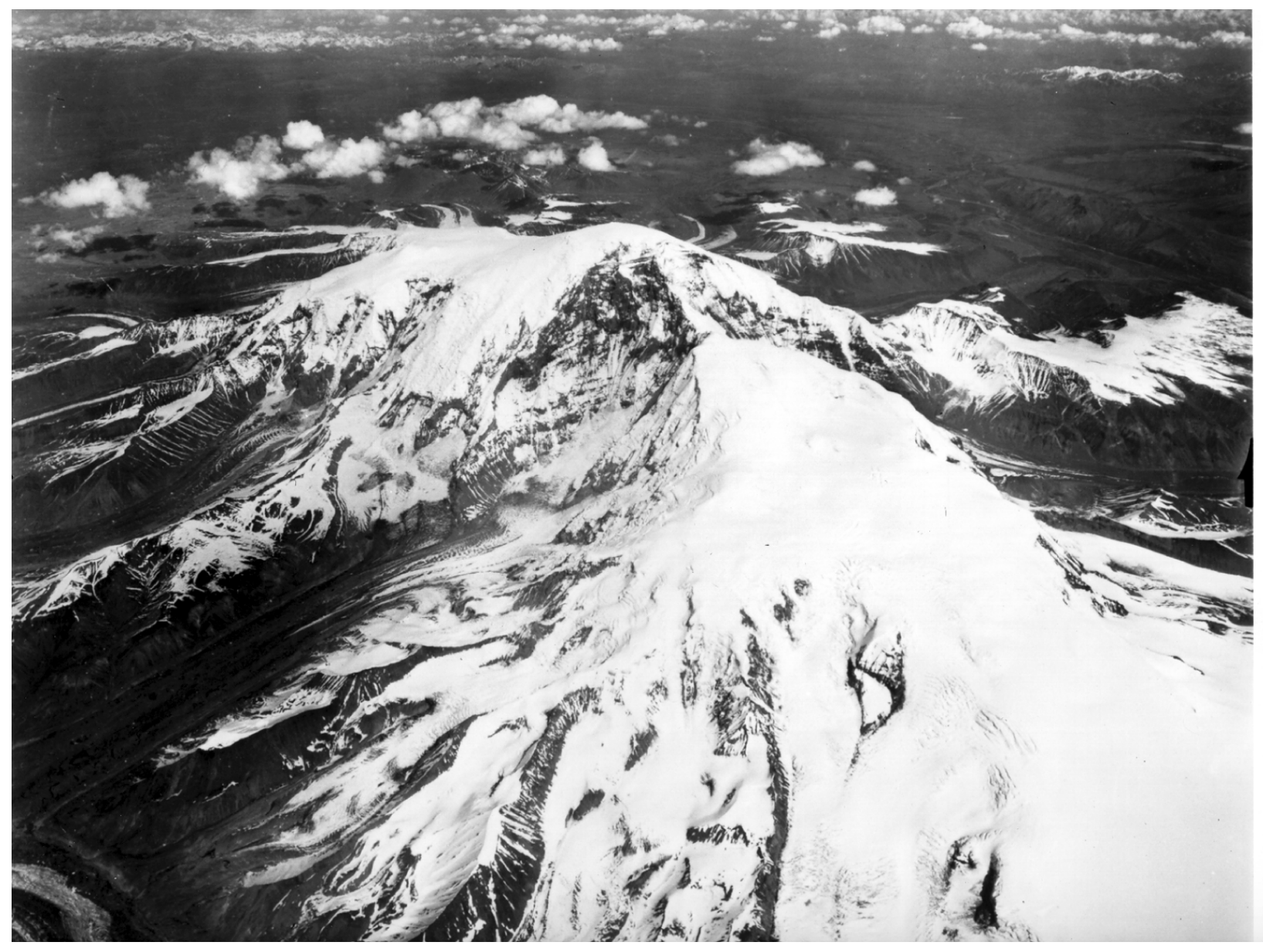

Figure 4. Oblique aerial view of southwest face of Mount Sanford. U.S. Army-Air Force Trimetrogon photo, June 15,1948 .

\begin{tabular}{|l}
$\begin{array}{l}\text { SHRUB MUD } \\
\text { VOLCANO }\end{array}$ \\
$\begin{array}{l}\text { ERUPTION } \\
\text { Energetic ejection of warm saline mud and } \mathrm{CO}_{2}\end{array}$ \\
\hline
\end{tabular}

Shrub is one of three large mud volcanoes of the Klawasi group located approximately $27 \mathrm{~km}$ (17 mi) east of Glennallen near the west slope of Pleistocene volcano, Mt. Drum, in the Copper River Basin of southcentral Alaska (fig. 5). The area is within Wrangell-St. Elias National Park and Preserve. Shrub rises $340 \mathrm{ft}$ ( 100 meters) above surrounding terrain and is composed of deposits derived from underlying glaciolacustrine sediments of the Basin (fig. 6)(Richter and others, 1998). Low-level mud and minor gas emission has historically been almost constant at the other two mud volcanoes; however, Shrub has been virtually inactive for decades with only some minor discharge observed in the mid-1950's (Nichols and Yehle, 1961). During the spring of 1997, Shrub began to vigorously erupt $\mathrm{CO}_{2}$-rich gas and warm saline mud. 


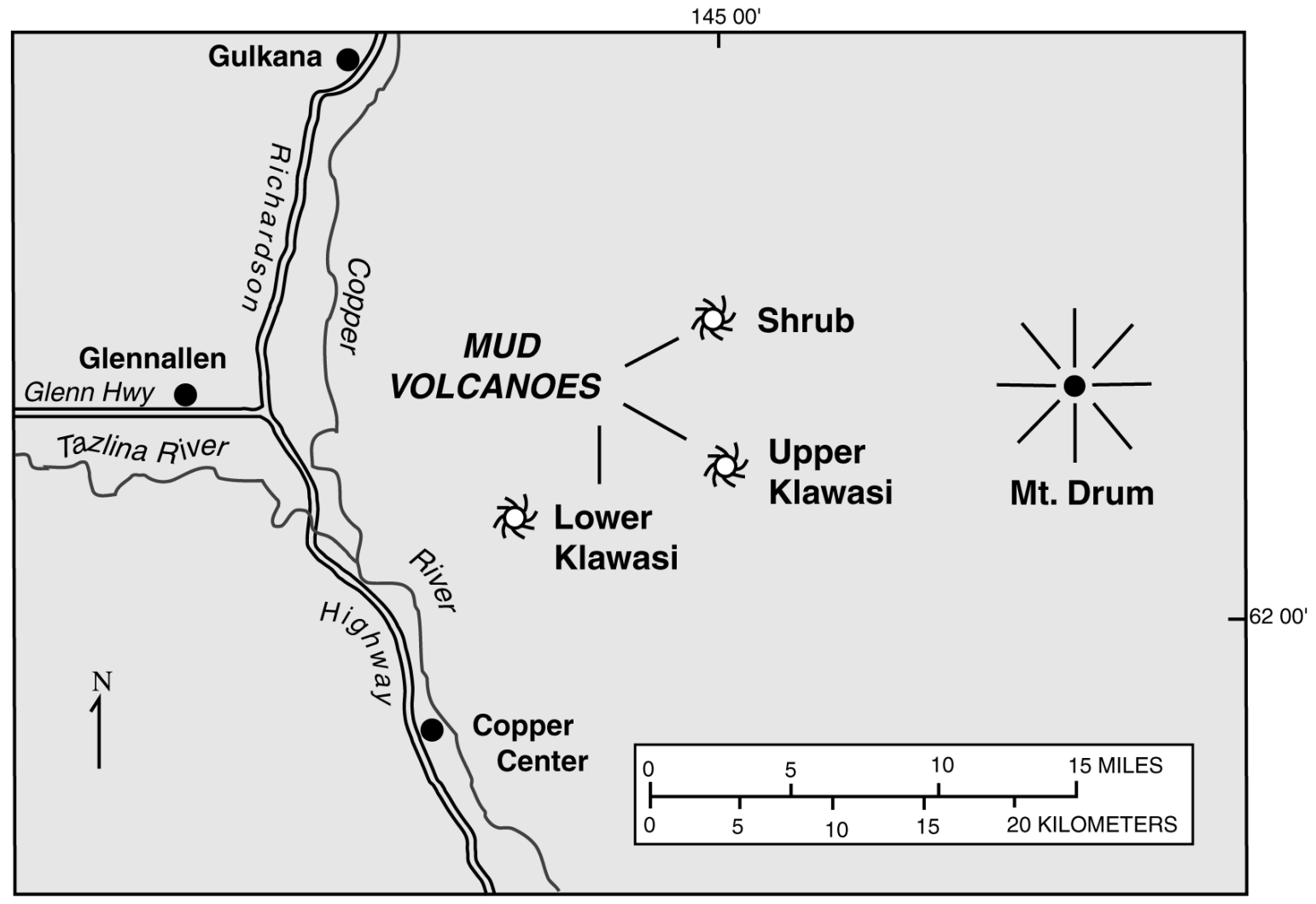

Figure 5. Location map for Shrub and Klawasi mud volcanoes (Richter and others, 1998).

Previously unreported observations indicate that initial low-level gas and mud discharge may have begun in 1996 (see Richter and others, 1998). The present activity was first noticed by Alaska Department of Fish and Game personnel on June 12, 1997. AVO and National Park Service field crews visited the site on June 21, June 30, and on August 13, 1997, and found that most of the gas and mud emission was occurring from at least four areas on the summit and north, northwest, and southeast flanks (fig. 7). The activity ranged from quiet effusion of $\mathrm{CO}_{2}$ from collapse pits to vigorous gushing of mud and gas from fissures and mud pots--some up to

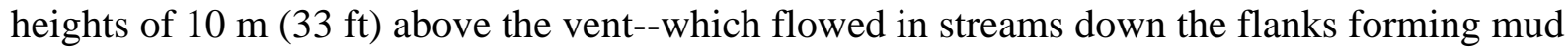
fans along the base of the cone (fig. 8). Measured mud temperatures were between $43.8^{\circ} \mathrm{C}$ $\left(110.8^{\circ} \mathrm{F}\right)$ and $46.4^{\circ} \mathrm{C}\left(115.5^{\circ} \mathrm{F}\right)$. Voluminous quantities of $\mathrm{CO}_{2}$ flowed as streams down the flanks in several locations, killing vegetation to heights of as much as 2 meters $(6.6 \mathrm{ft})$ above the ground surface. Small mammals and birds perished around several of the $\mathrm{CO}_{2}$ vents, indicating a potential $\mathrm{CO}_{2}$ hazard.

Following the August site visit and AVO hazard assessment, the National Park Service issued a formal public warning of potentially dangerous $\mathrm{CO}_{2}$ levels at the volcano. An aerial survey of the area on December 2, 1997, confirmed that mud and gas discharge continues. Richter and others (1998) summarize the 1997 activity and present chemical analyses of the gas and mud. 


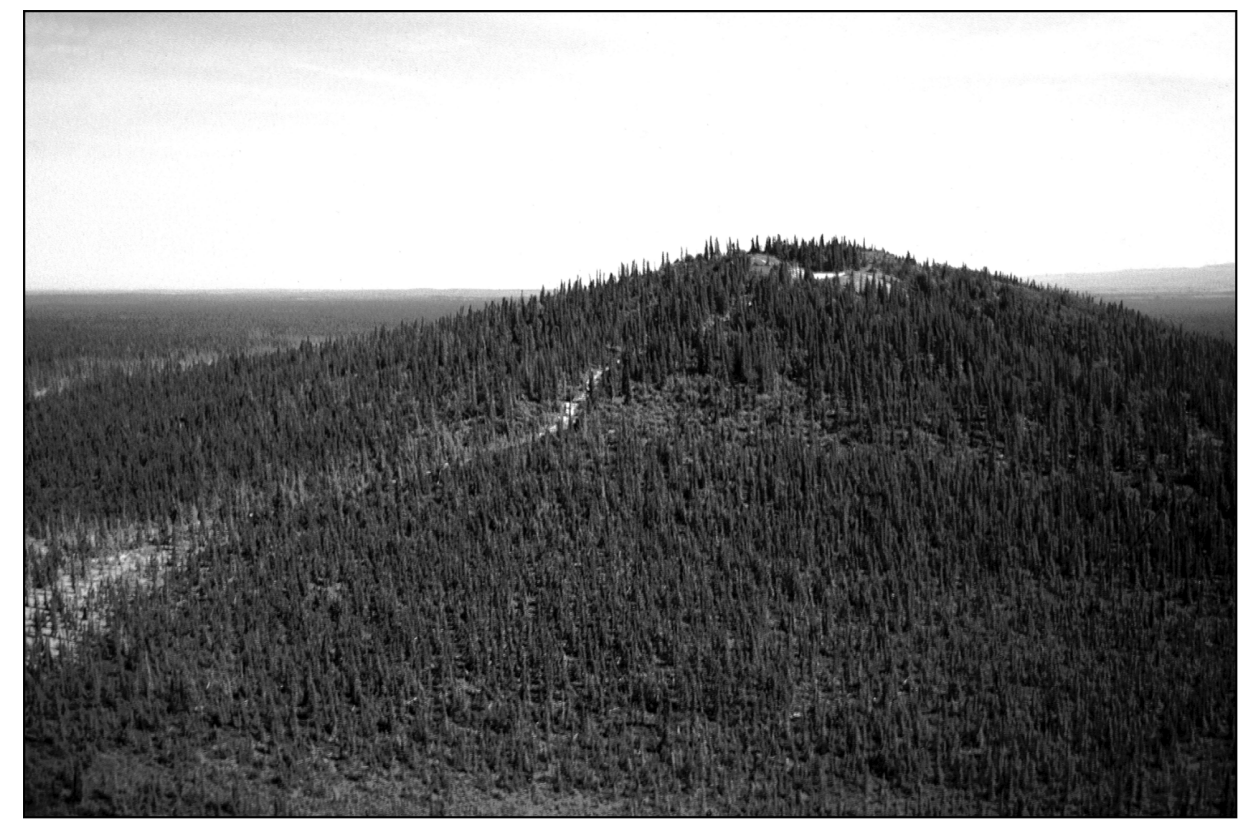

Figure 6. Oblique aerial view of Shrub mud volcano, 8/13/97.

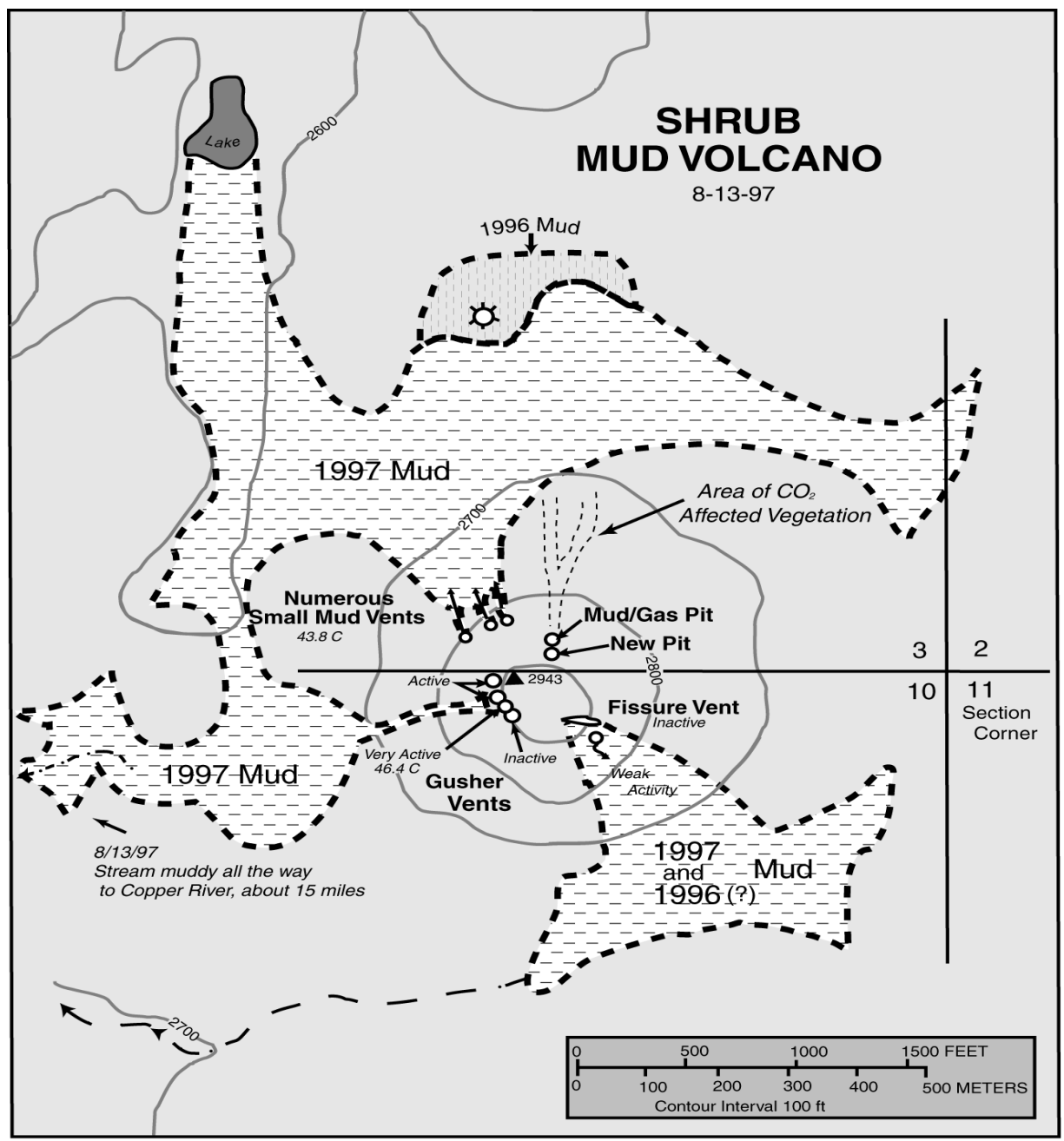

Figure 7. Sketch map showing major $\mathrm{CO}_{2}$ and mud vents, and distribution of mud deposits (Richter and others, 1998). 


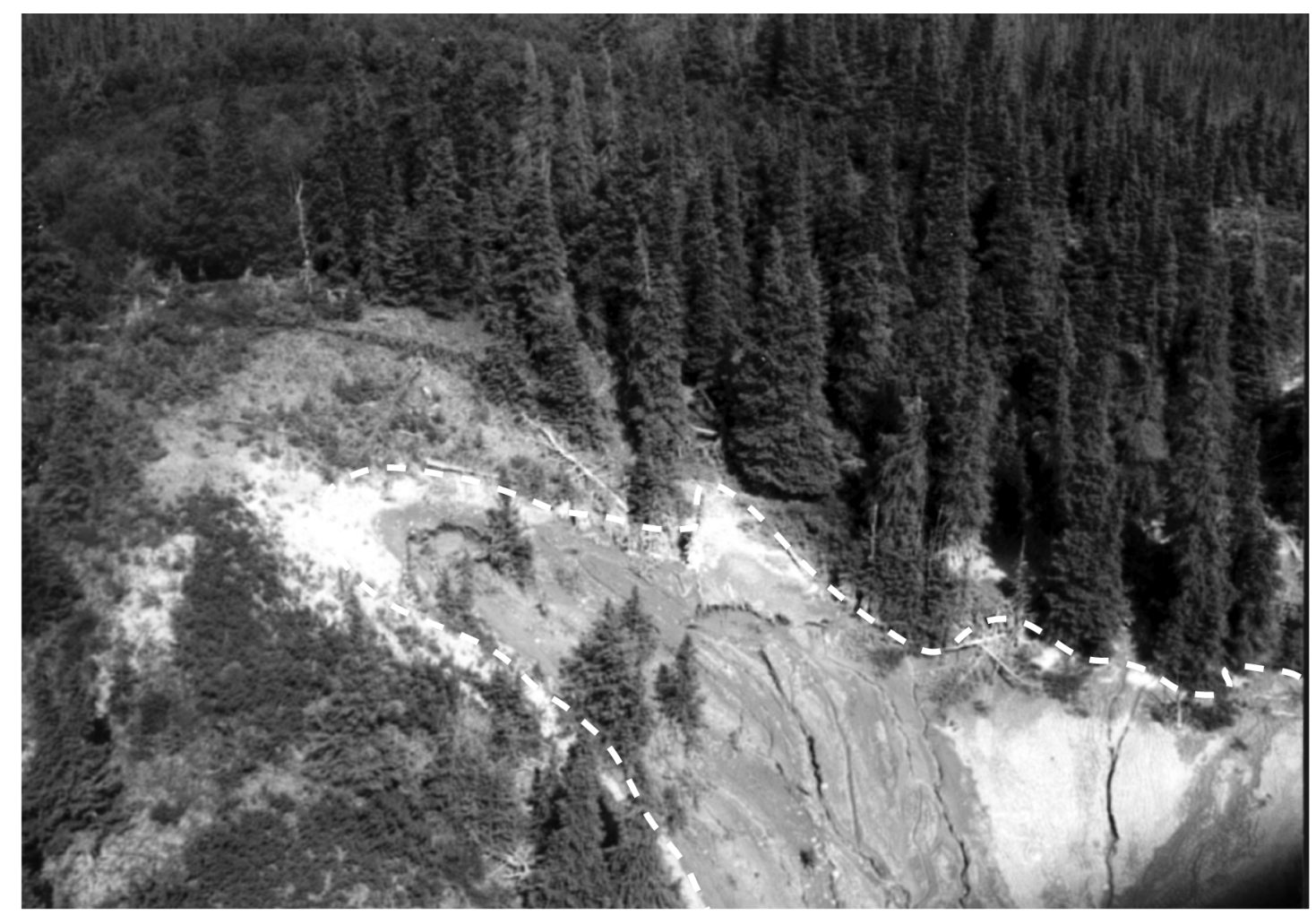

A

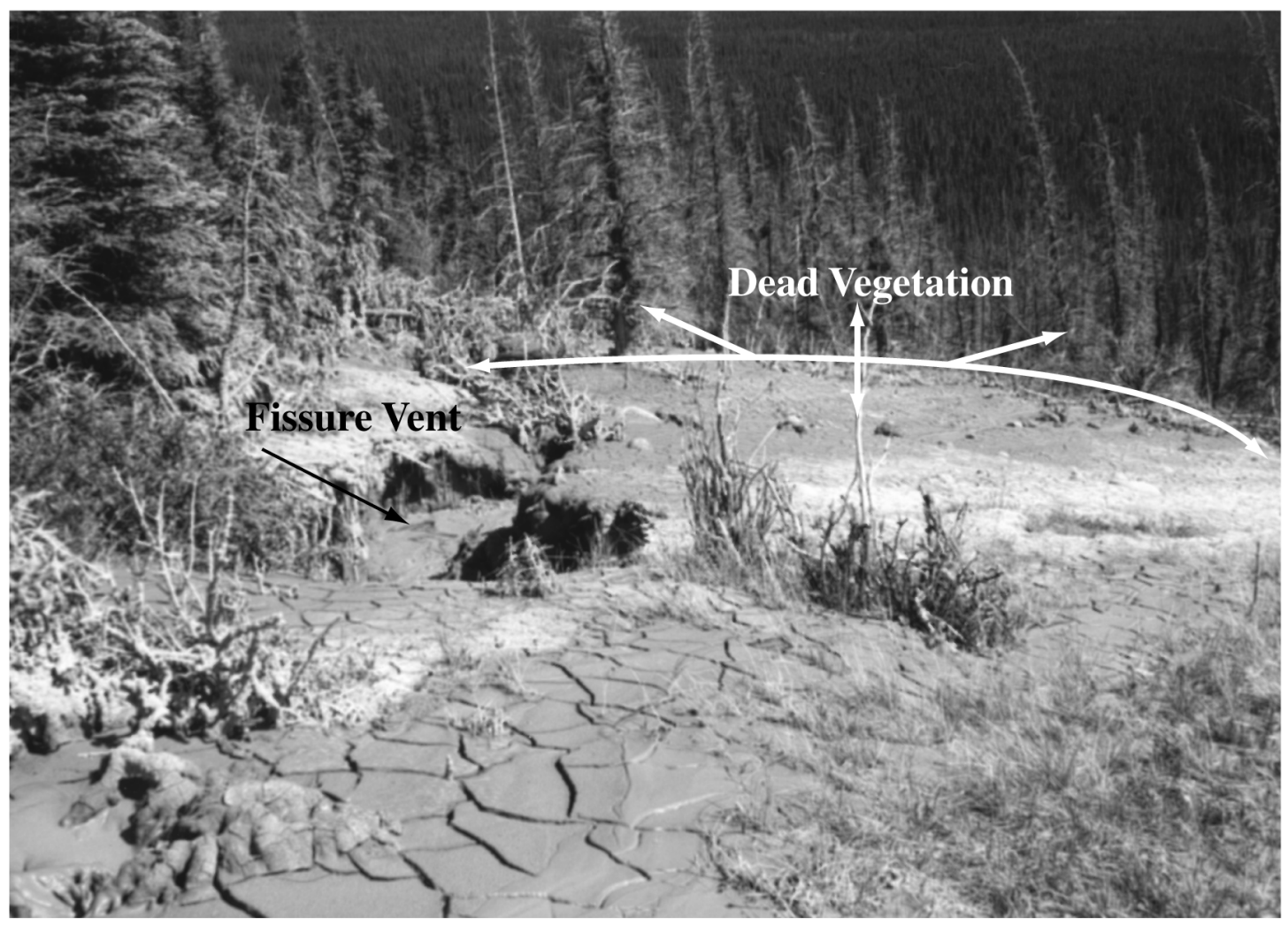

B

Figure 8. A. Summit area of Shrub mud volcano and the "Gusher Vents". B. Fissure vent on upper eastsoutheast flank. Refer to fig. 7 for locations. Photos by Don Richter, 6/21/97. 


ILIAMNA
VOLCANO
SEISMIC SWARM
Elevated seismicity declines
SUSPECT VOLCANIC ACTIVITY
Snow and rock avalanche

Iliamna Volcano is a deeply eroded, ice-and snow-covered stratovolcano located $225 \mathrm{~km}$ (140 mi) southwest of Anchorage. The upper flanks are pervasively altered from hydothermal activity and periodically produce rockfalls and avalanches. No historical eruptive activity has been documented. However, a prominent fumarole field near the summit produces a near constant steam plume, which is often mistaken for eruptive activity. AVO maintains and monitors a 6-station seismic network on Iliamna.

The last of two recent seismic swarms at Iliamna began in July 1996, peaked in late August 1996, continued intermittently until the end of the year, and gradually declined over the next several months returning to background seismic levels by early March, 1997 (Neal and McGimsey, 1997). $\mathrm{SO}_{2}$ and $\mathrm{CO}_{2}$ fluxes also followed a similar pattern. AVO closely monitored the volcano and reported the status of activity in weekly updates through March 21, 1997. The end of the seismic swarm was also reported in the Global Volcanism Network (GVN) bulletin (Smithsonian Institution, 1997a).

On May 19, 1997, seismicity at Iliamna abruptly and dramatically increased. Analysis by AVO seismologists suggested that the activity probably resulted from a local avalanche or rockslide. A large avalanche of mixed snow, rock, and ice cascaded down the east flank on June 30, 1994, producing a similar seismic signature (Neal and others, 1995). An AVO field crew dispatched to make observations verified that indeed a large avalanche, composed mostly of ice and snow with some rock debris, had originated at the 7,500-foot ( 2,300-meter) level and had cascaded down the east flank, mimicking the 1994 avalanche. The incident was not mentioned in the AVO weekly update.

\begin{tabular}{|lrrr|r|}
\hline KATMAI GROUP & $58^{\circ} 10^{\prime} \mathrm{N}$ & $155^{\circ} 21^{\prime} \mathrm{W}$ & $6,102 \mathrm{ft}(1,860 \mathrm{~m})$ & Martin \\
$58^{\circ} 12^{\prime} \mathrm{N}$ & $155^{\circ} 15^{\prime} \mathrm{W}$ & $7,103 \mathrm{ft}(2,165 \mathrm{~m})$ Mageik \\
$58^{\circ} 16^{\prime} \mathrm{N}$ & $154^{\circ} 59^{\prime} \mathrm{W}$ & $6,716 \mathrm{ft}(2,047 \mathrm{~m})$ Katmai \\
$58^{\circ} 20^{\prime} \mathrm{N}$ & $154^{\circ} 44^{\prime} \mathrm{W}$ & $7,090 \mathrm{ft}(2,161 \mathrm{~m})$ Snowy \\
$58^{\circ} 28^{\prime} \mathrm{N}$ & $154^{\circ} 21^{\prime} \mathrm{W}$ & $6,693 \mathrm{ft}(2,040 \mathrm{~m})$ Kukak \\
SUSPECT VOLCANIC ACTIVITY &
\end{tabular}

Mageik and Martin are large, adjacent, mostly ice-covered stratovolcanoes in the Katmai group, located within Katmai National Park and Preserve on the Alaska Peninsula (fig. 1). Other than 
fumarolic activity from summit craters, there are no credible reports of historical activity at either volcano. Steam emission from the 500-meter-wide (1,640 ft) summit crater of Martin is vigorous and nearly continuous, with plumes occasionally rising 2,000 ft $(\sim 600 \mathrm{~m})$ or more above the vent and extending downwind for up to $10 \mathrm{mi}(16 \mathrm{~km})$. Steam plumes rising from hot pools in the summit crater of Mageik are also common.

On Thursday, February 19, 1997, AVO received multiple pilot reports (PIREPs) of ash and steam rising to 5,000 ft $(\sim 1,500 \mathrm{~m})$ above either Martin or Mageik volcanoes. No anomalous seismic activity was recorded on the Katmai seismic network, and no indication of eruptive activity was detected on satellite imagery. No mention of the PIREPs was made in the AVO weekly update. Similar activity was reported in 1992 (McGimsey and others, 1995), 1994 (Neal and others, 1995), and 1995 (McGimsey and Neal, 1996).

Another observation of unusual steaming at Martin and Mageik was reported to AVO on December 11, 1997, via the Alaska Tsunami Warning Center, who received the report from a resident of Karluk Village on Kodiak Island. Using a spotting scope, the village resident had observed the peaks for the previous three weeks--noting no unusual activity--when on the morning of the 11th he witnessed a sudden increase in steam activity and watched as white, towering steam clouds billowed from Martin, subsided, and then rose again to about 600-700 ft $(\sim 200 \mathrm{~m})$ above the vent, forming a large mushroomed top before dissipating. A second white, billowing steam plume then rose from adjacent Mageik. Local pilots also noted the unusually vigorous activity. AVO responded by analyzing seismicity and satellite imagery, querying the Center Weather Unit at FAA for PIREPs, contacting the observer in Karluk Village, and discussing local weather conditions with the NWS. Seismicity was normal and regional clouds obscured the activity on satellite imagery. No PIREPs were logged. The observer reported the activity had subsided within a couple of hours. The NWS reported that weather conditions in the area were apt to enhance any clouds along and over the mountains of the Katmai Group.

On Wednesday, June 3, 1997, a U.S. Coast Guard helicopter crew reported greenish discoloration on snow and steaming from several vents on a 7,000-ft-high $(\sim 2,100 \mathrm{~m})$ peak north and east of Mt. Katmai. A minor anomaly was noted on satellite imagery and the source of the activity was suspected to be either Snowy Mountain or Kukak Volcano, both of which have active fumaroles (Wood and Kienle, 1990). During the early 1980s, fumarolic activity was more vigorous at Kukak than at Snowy (C. Nye, oral communication). Both volcanoes are extensively ice covered (fig. 9). The fumarolic activity and lack of significant erosional dissection of the flanks suggests youthful activity; however, no historic eruptions have been reported. 


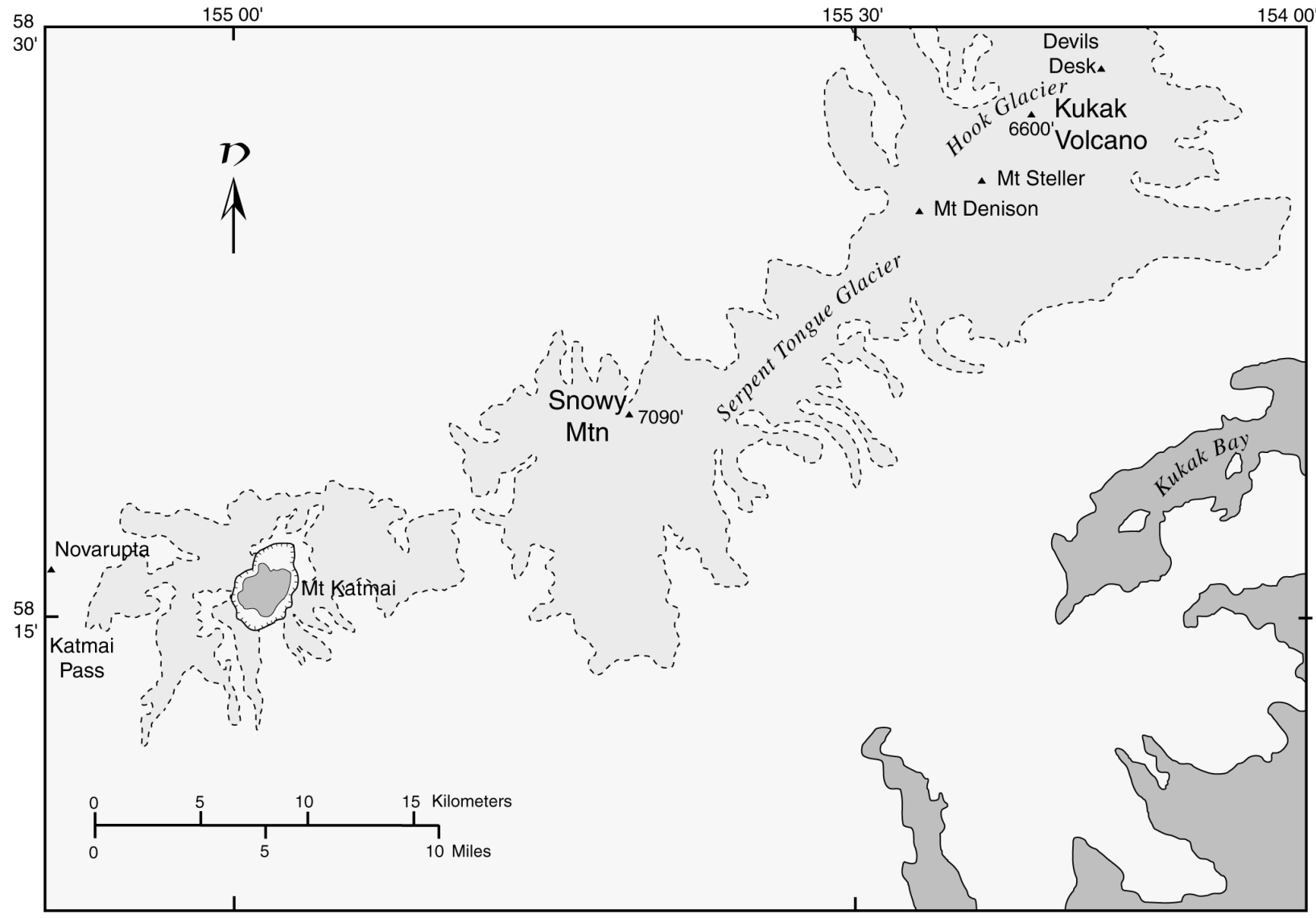

Figure 9. Sketch map showing location of Snowy Mountain and Kukak Volcano with respect to Mt. Katmai. Ice and perennial snow indicated by shaded area bounded by dashed lines; hachured line delineates Katmai caldera.

\section{CHIGINAGAK VOLCANO}

$57^{\circ} 08^{\prime} \mathrm{N} \quad 157^{\circ} 00^{\prime} \mathrm{W}$

$7,005 \mathrm{ft}(2135 \mathrm{~m})$

\section{MINOR ERUPTIVE ACTIVITY}

Significantly increased steaming and development of new fumarole field

Chiginagak is a symmetric stratovolcano located $175 \mathrm{~km}(110 \mathrm{mi})$ south of King Salmon on the Alaska Peninsula. The nearest settlement is Pilot Point, $60 \mathrm{~km}(37 \mathrm{mi})$ to the northwest. The upper half of the volcano is snow- and ice-covered, and a prominent fumarole located high on the north flank at about 5,500 ft $(\sim 1,675 \mathrm{~m})$ constantly emits steam and sulfur gases. Historic eruptive activity has been minor and poorly documented, however, the volcano is surrounded by young pyroclastic deposits and lava flows. No seismic instruments have been installed.

On October 22, 1997, AVO began receiving pilot reports of increased steaming, snowmelt, and sulfur smell at Chiginagak. Residents of Pilot Point and surrounding areas also reported that they began noticing an increase in steam emissions possibly as early as mid-summer 1997. A thermal anomaly was detected on Advanced Very High Resolution Radiometer (AVHRR) imagery analyzed on October 23, 1997 (fig. 10). During a flight around the volcano on October 
30, AVO scientists observed an enlarged area of fumarolic activity and new fumaroles at about $6,300 \mathrm{ft}(\sim 1,900 \mathrm{~m})$, directly above the previously known fumarole site.

AVO reported the activity at Chiginagak in the weekly update of October 31, 1997 and in updates through year's end, including GVN (Smithsonian Institution, 1997b). Daily, and later weekly, correspondence was maintained with local residents for observations, and AVO closely monitored satellite imagery for signs of increased activity.

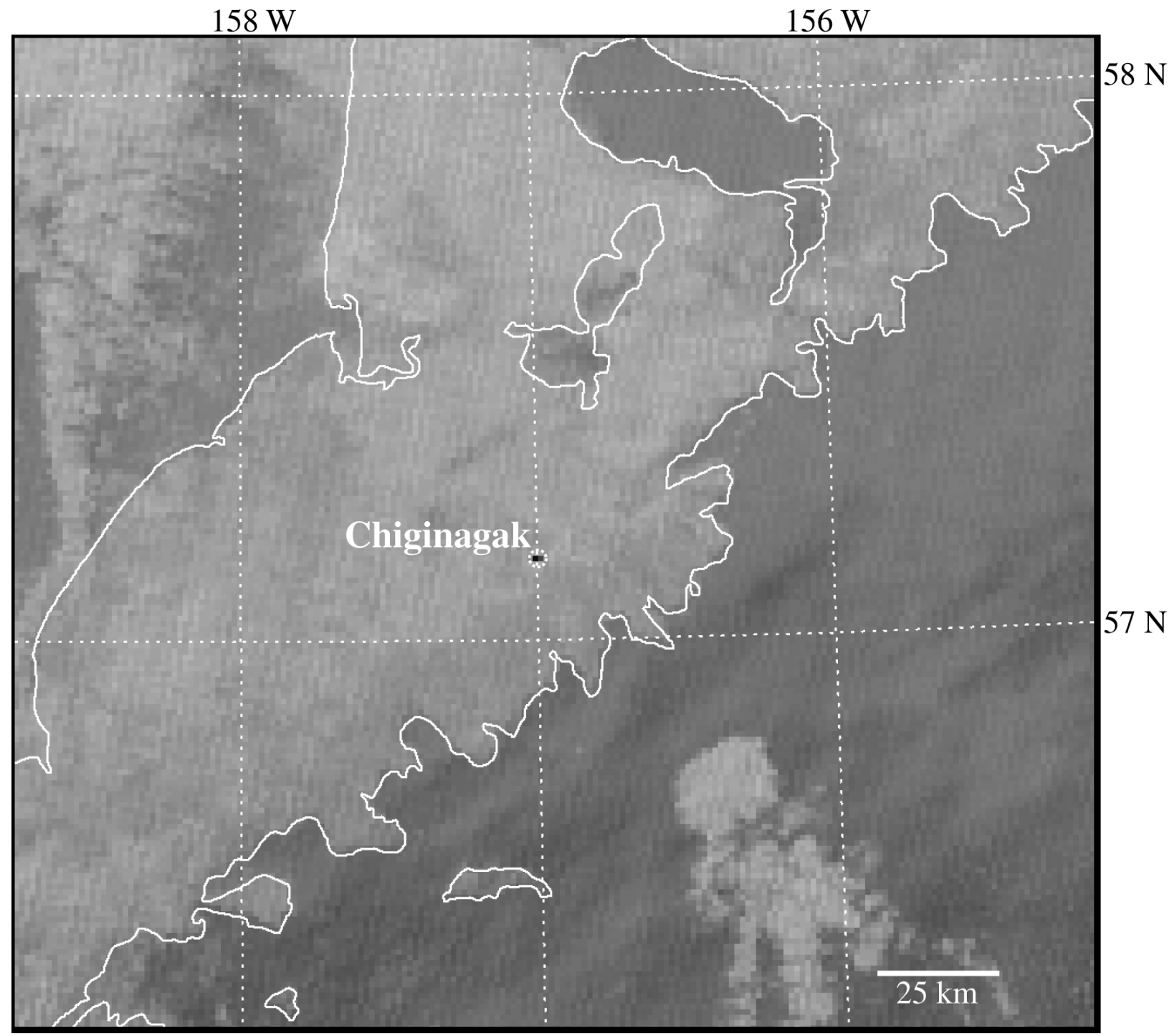

Figure 10. Chiginagak: AVHRR band 3 image collected on October 23, 1997. In this image hot features are dark, and cold features are bright. A small, 2-pixel thermal anomaly is observed in this image as a small black spot. This thermal anomaly was first observed in AVHRR imagery on this day, and was last observed on October 27. 


\begin{tabular}{llll|}
\hline PAVLOF VOLCANO & $55^{\circ} 25^{\prime} \mathrm{N}$ & $161^{\circ} 53^{\prime} \mathrm{W}$ & $8,264 \mathrm{ft}(2,519 \mathrm{~m})$ \\
ERUPTION & & \\
Conclusion of eruption that began in 1996 & & \\
\hline
\end{tabular}

Pavlof, the most frequently active of Alaska's volcanoes (40 eruptions since 1790), began a strombolian eruption in September 1996, that continued into January 1997. The eruption was characterized by lava fountains, lava flows, lahars, and ash plumes to more than 35,000 ft ( 10.6 $\mathrm{km})$ ASL causing temporary disruption of air traffic (Neal and McGimsey, 1997). The eruption was observed (weather permitting) by residents of Cold Bay, $60 \mathrm{~km} \mathrm{(37} \mathrm{mi)} \mathrm{southwest} \mathrm{of} \mathrm{the}$ volcano. AVO installed a six-station seismic network about a month prior to onset of the eruption. Although the eruption was deemed largely over by the end of January 1997, AVO maintained daily and weekly contact with observers in Cold Bay as well as closely monitoring seismicity, satellite imagery, and pilot reports for the next several months. Pavlof continued to be featured in AVO's weekly update through April 4, 1997, when the Level Of Concern Color Code, which had been YELLOW since December 29, 1996, was reduced to GREEN (Table 4). Over the next few months, occasional pilot and observer reports were recorded, and AVO continued vigilant monitoring of seismicity and satellite imagery.

On Sunday, June 1, 1997, a slight increase in seismicity and observations from NWS in Cold Bay of vigorous steaming prompted AVO to raise the Level of Concern Color Code to YELLOW and issue an update on Monday, June 2, 1997. Thermal anomalies were visible on satellite imagery, and the elevated seismicity continued through the week. By the following week, the activity had declined and the Level of Concern Color Code was returned to GREEN on Friday, June 13, 1997, which was the last mention of Pavlof in the weekly updates for the remainder of the year. Field observations in July revealed that the cone was blanketed with dark ash, most of the glacial ice was still intact, and there was no active degassing from the debrisfilled vent in the summit crater (Smithsonian Institution, 1997a).

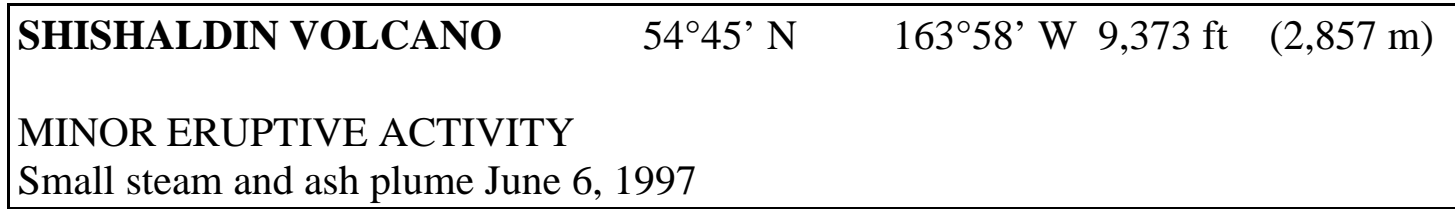

Shishaldin Volcano, located about 1,100 km ( 680 mi) southwest of Anchorage near the center of Unimak Island, is a spectacular symmetric stratocone that forms the highest peak in the Aleutian Islands. Shishaldin is one of the most active volcanoes in the Aleutian arc with at least 27 eruptions since 1775 (Miller and others, 1998). The last eruptive period occurred in 1986-87 and consisted of steam and minor ash emission. Strombolian eruptions and ash and steam emissions characterize most of the documented eruptive activity at Shishaldin Volcano. Nearly constant fumarolic activity within the summit crater produces a steam plume that can occasionally be quite vigorous and typically results in numerous false eruption reports. The nearest community is False Pass, $32 \mathrm{~km}$ (20 mi) east-northeast of the volcano. On Monday afternoon, June 2, 1997, a NWS observer in Cold Bay, $96 \mathrm{~km}$ (60 mi) northeast of the volcano, viewed through field glasses a steam and ash plume rising about 1,000-1,500 ft 
$(\sim 300-450 \mathrm{~m})$ above the summit vent and drifting 3-4 mi $(5-6 \mathrm{~km})$ to the north. At the time, the volcano was not seismically monitored. This eruptive activity appears to be similar to that documented in 1993 (Neal and others, 1996), and 1994 (Neal and others, 1995). The observation was added to a special update issued on June 2 reporting increased activity at Pavlof Volcano. Shishaldin was last mentioned in the June 13, 1997, weekly update since AVO received no further information from pilots, local observers, and satellite imagery.

\section{OKMOK VOLCANO}

$$
53^{\circ} 24^{\prime} \mathrm{N}
$$

$168^{\circ} 10^{\prime} \mathrm{W}$

$3,520 \mathrm{ft} \quad(1,073 \mathrm{~m})$

\section{ERUPTION}

Strombolian eruption from intracaldera Cone A begins on February 13, 1997, and produced ash clouds and extensive lava flows during the following 6 weeks prompting FAA to issue a NOTAM

Okmok is a 10-km-wide (6 mi), 2,400-year-old caldera that forms the northeastern end of Umnak Island, $120 \mathrm{~km}(75 \mathrm{mi})$ southwest of Dutch Harbor in the central Aleutian Islands (fig. 11). The nearest settlements are Nikolski, population about 35 , located $72 \mathrm{~km}$ (45 mi) west of the volcano, and a small number of ranch personnel at the abandoned Fort Glenn military base $16 \mathrm{~km}(10 \mathrm{mi})$ east of the caldera. The caldera contains more than 8 cinder cones and effusive vents (fig. 12). Cone A, a cinder cone located near the southwest caldera wall, is suspected to be the source of most if not all the historic eruptive activity (Byers, 1959; Miller and others, 1998). The volcano has had several major historic eruptions and a dozen minor eruptive events, which occasionally resulted in ash emission to over 30,000 ft $(\sim 9,000 \mathrm{~m})$. The explosive eruption of 1817 buried an Aleut village located at Cape Tanak, $13 \mathrm{~km}(8 \mathrm{mi})$ from the caldera rim along the north shore (Miller and others, 1998). Lava flows extended across the caldera floor in 1945 and 1958 (fig. 12). The last eruption, November 1986 through February 1988, was characterized by intermittent ash emission. AVO does not have seismic instruments on Umnak Island.

The first sign of restlessness at Okmok was a steam plume rising from Cone A on November 11, 1996, that was noticed by a commercial pilot. On February 11, 1997, a dark plume was observed over Okmok by a pilot and passengers enroute to Dutch Harbor. Neither of these observations was initially reported to AVO. We first detected anomalous activity as a hot spot on a thermal-infrared band satellite image on the morning of February 13, 1997. Shortly thereafter, ranchers at Fort Glenn contacted AVO via satellite phone to report a dark ash plume rising from the caldera to 5,000 $\mathrm{ft}(\sim 1,500 \mathrm{~m})$ ASL, drifting to the southwest. AVO issued an information release about noon on February 13 and began close monitoring of the situation. No color code was assigned due to lack of seismic instrumentation.

Poor weather prevented observation for the next few days until February 20, when the ranchers at Fort Glenn saw a bright red glow reflected from weather clouds that morning over the volcano--the first verification of lava production--and U.S. Coast Guard pilots reported an ash plume rising from the volcano to between 10,000 and 15,000 $\mathrm{ft}(\sim 3,000$ and 4,600 $\mathrm{m})$ ASL. AVO satellite imagery analysis revealed a 22-pixel hotspot in the caldera on February 22 (fig. 13). Several days later, a Fort Glenn rancher climbed to the caldera's south rim and observed a 0.5 to 0.9 -mi-long ( 0.8 to $1.5 \mathrm{~km}$ ) lava flow extending northeast from Cone A. Over the next week, satellite imagery analyses and pilot reports verified that the eruption was ongoing. On 
February 28, a NOAA marine mammals research crew surveyed the eruptive activity by helicopter and witnessed spectacular strombolian lava fountaining, ballistic showers, and bubble bursts (see front cover). They also documented several lava flows extending 3-4 mi $(5-6 \mathrm{~km})$ across the caldera floor from Cone A (fig. 14 and cover photo). On March 11, a pilot reported a short-lived plume of steam and ash up to 30,000 ft (9,000 m) ASL drifting northwest, prompting FAA to issue a NOTAM (see glossary). Over the next 3 weeks, AVO received 8 PIREPs of ash clouds from $\mathrm{m} 8,000 \mathrm{ft}$ to $16,000 \mathrm{ft}$ ( 2,500 $\mathrm{m}$ to 5,000) ASL. By March 27, a visual observation revealed that the activity level had substantially declined. Over the next several months, occasional ash bursts and thin, low level plumes were reported, and satellite image analyses revealed persistent hotspots in the caldera (fig. 15). SAR imagery (see glossary) taken on November 5, 1997, shows lava flows extending northeastward nearly across the caldera floor, covering much of the 1958 lava flow (fig. 11). The eruptive activity at Okmok was reported in AVO weekly updates from February 14, 1997, through May 23, 1997, and in the January-April issues of the GVN bulletin (Smithsonian Institution, 1997c).

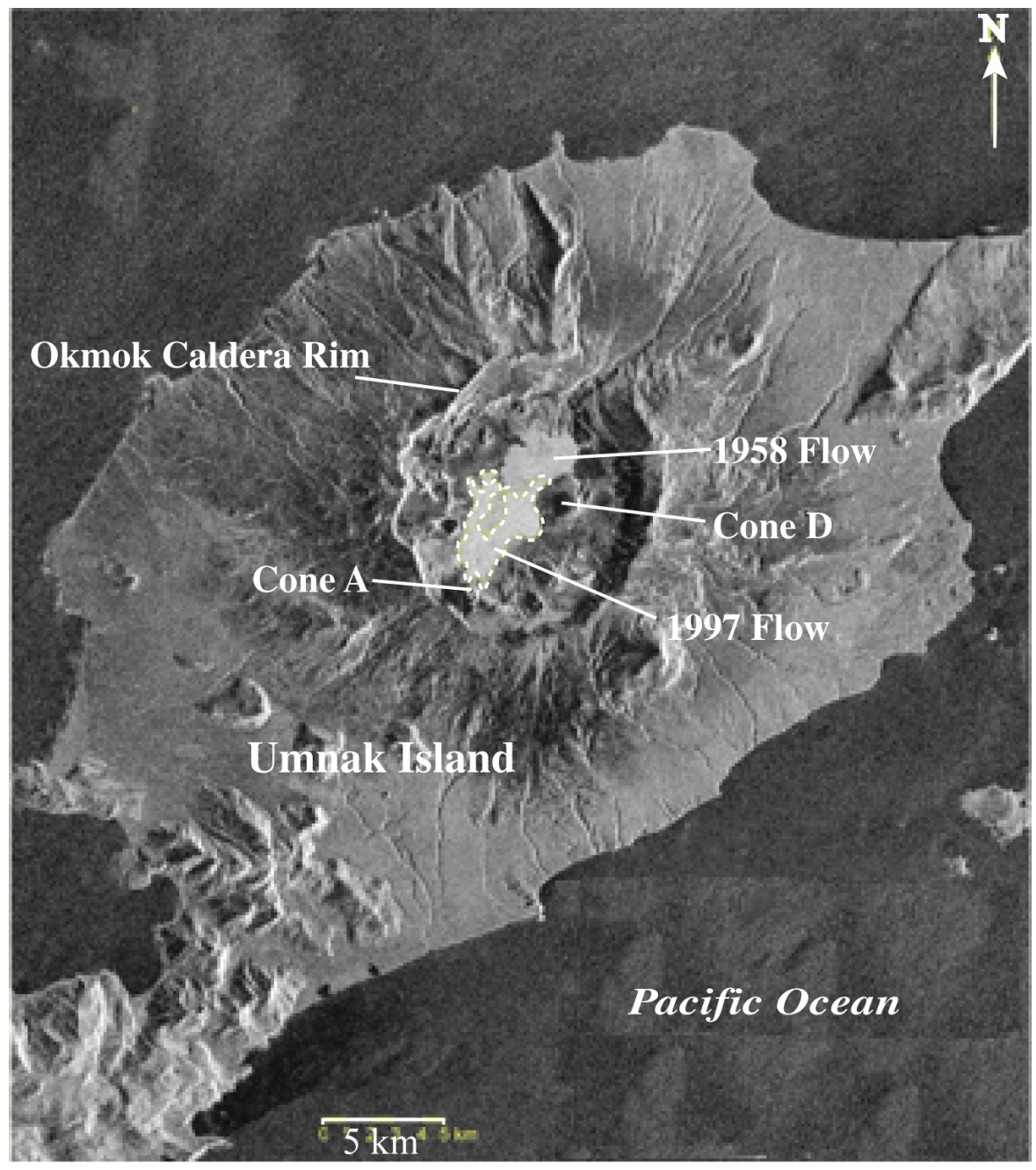

Figure 11. Japanese Earth Resources Satellite image taken November 5, 1997, of Okmok caldera in the northern half of Umnak Island. Extent of the 1997 lava flows is shown by dashed line. 


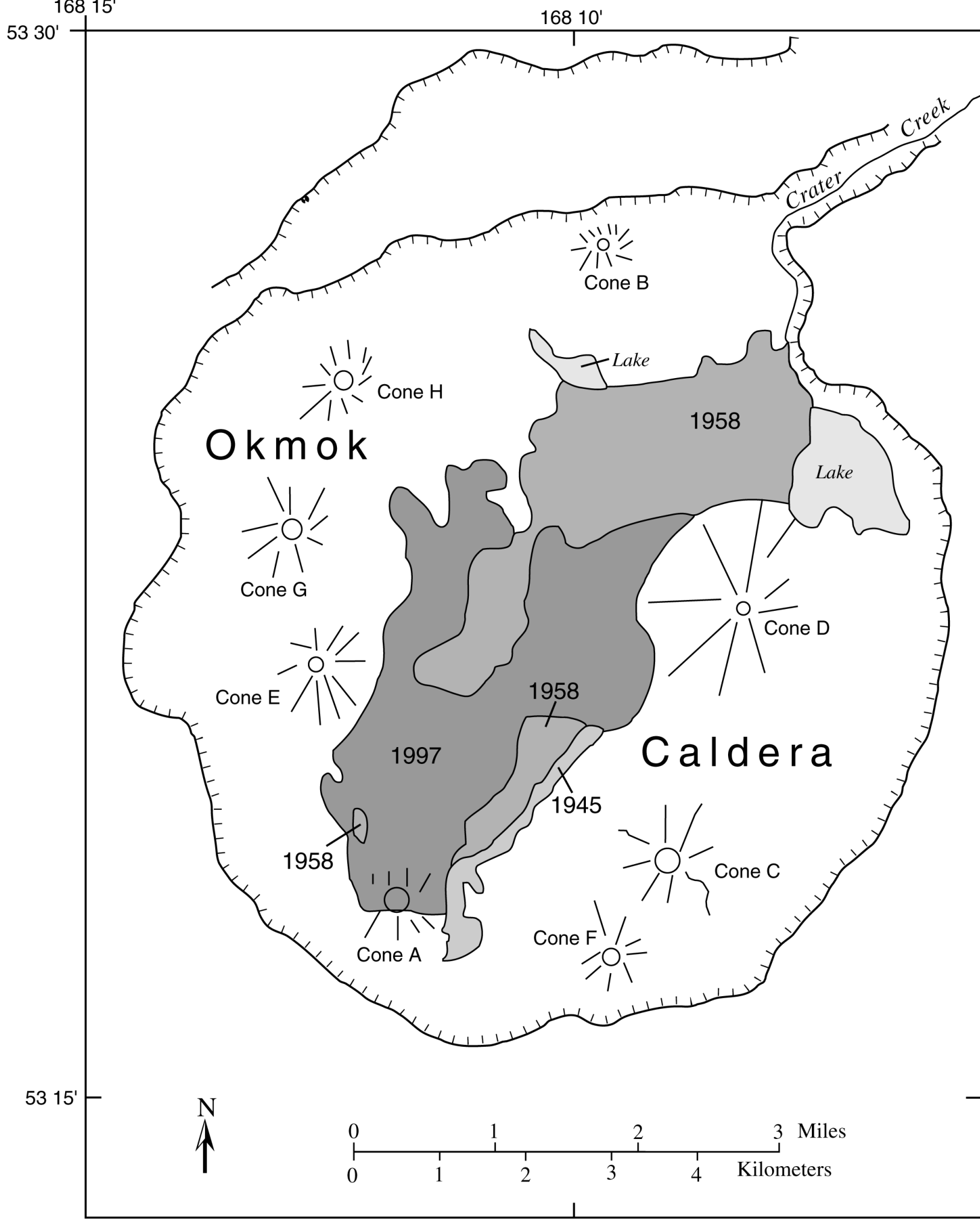

Figure 12. Sketch map of Okmok caldera showing intracaldera cones (youngest to oldest A-G, Byers, 1959), and the extent of the 1945, 1958, and 1997 lava flows. 


\section{Okmok Caldera Rim}

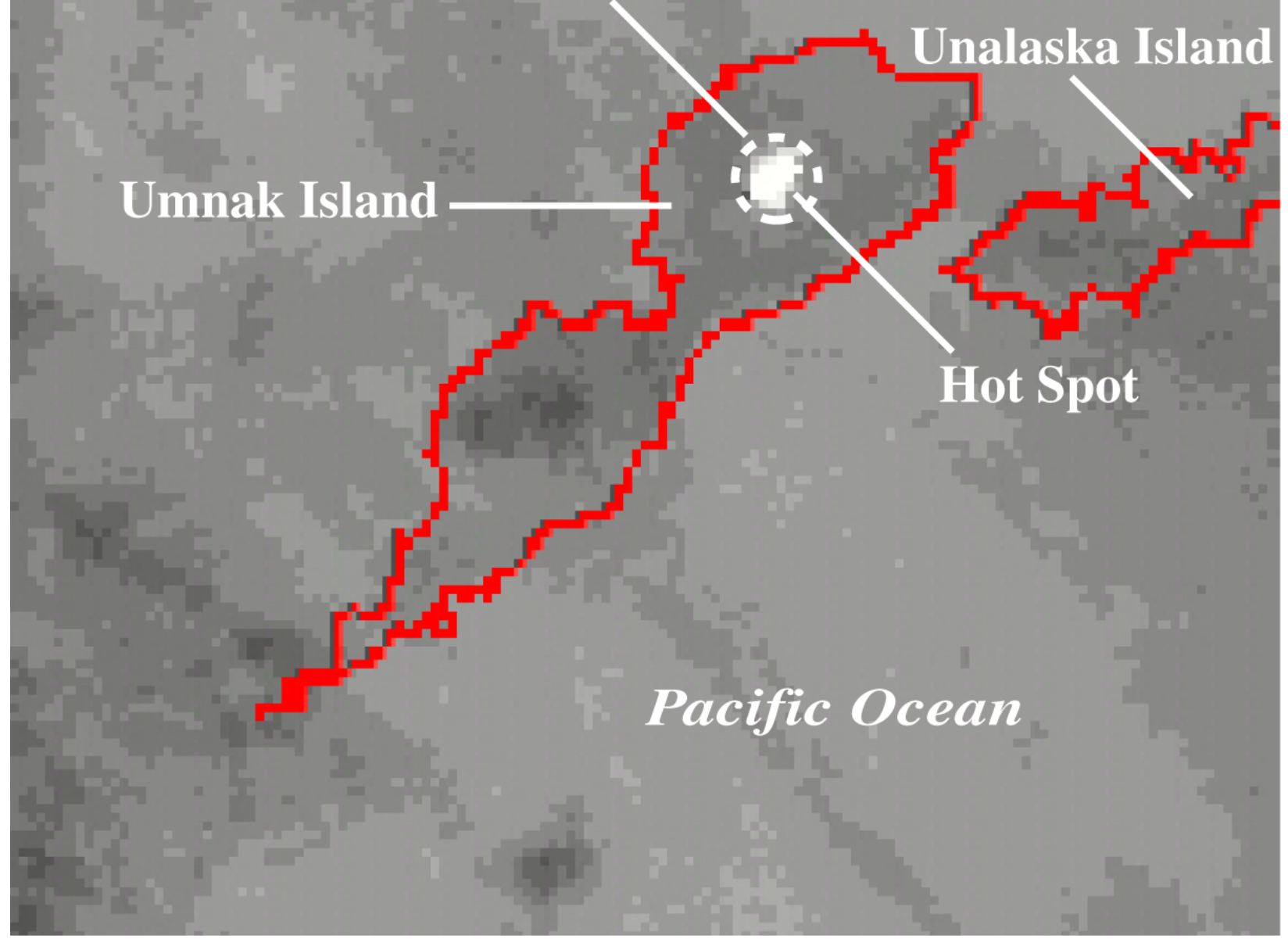

Figure 13. Advanced very high-resolution radiometer (AVHRR) band 3 image of a thermal anomaly at Okmok Volcano, February 22, 1997. The size of the hot spot is 22 pixels (white) and is located near the center of the caldera (dashed line). 


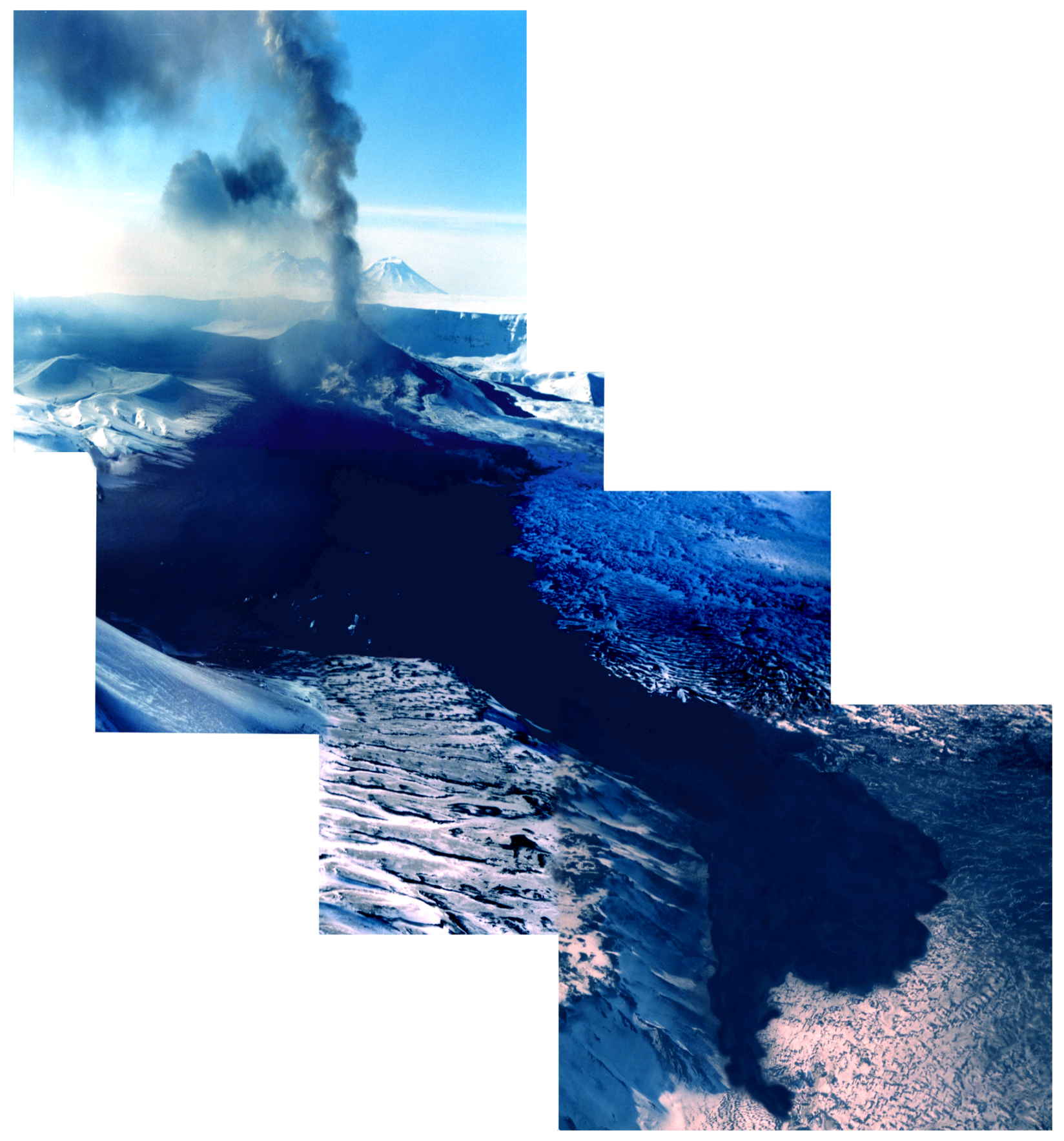

Figure 14. Composite photo showing lava flow from Cone A in Okmok caldera extending to the base of Cone D (see figure 12). Photos by John Sease, NOAA National Marine Mammals Laboratory, 2/28/97. 


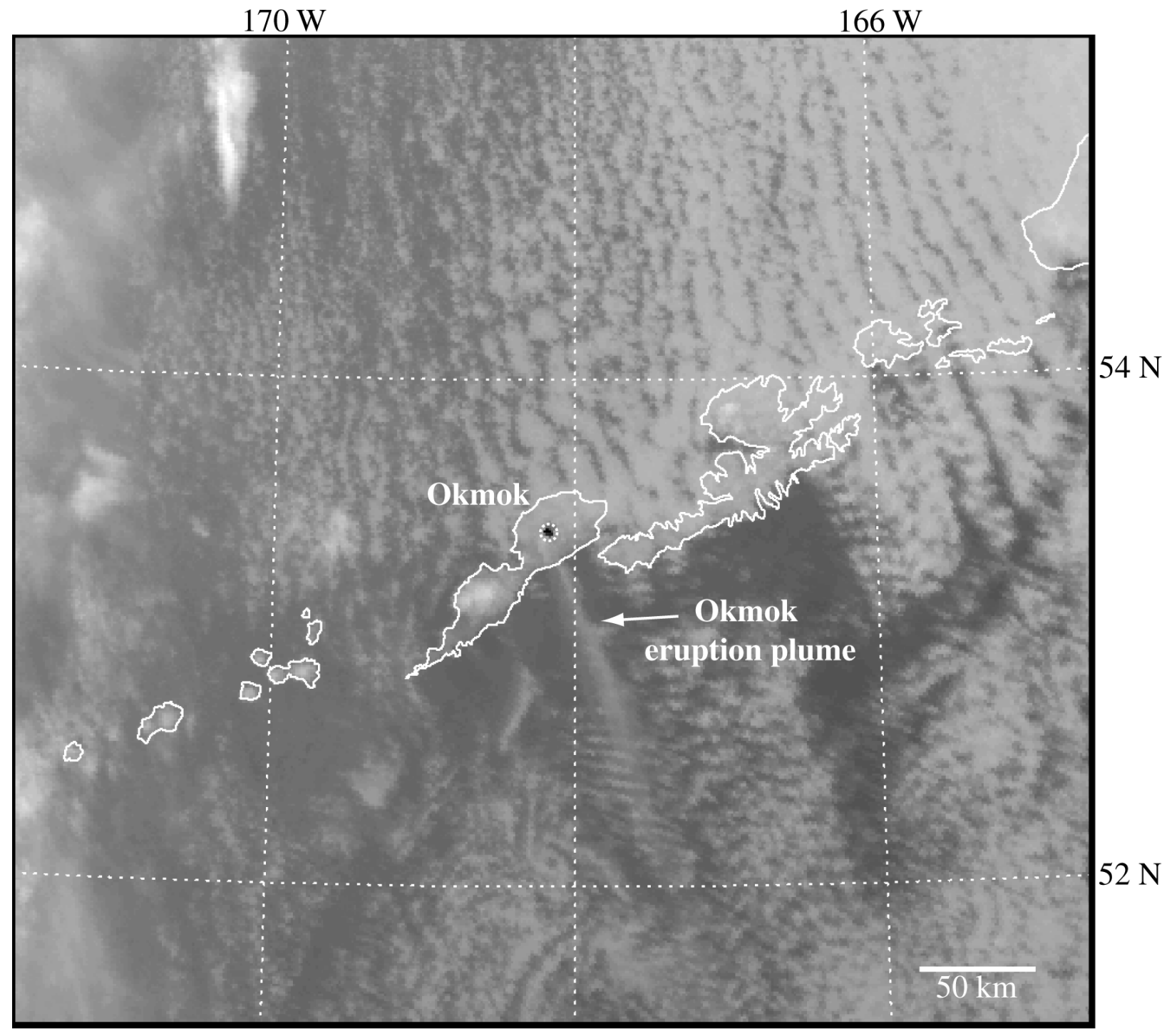

Figure 15. AVHRR band 4 image collected on April 1, 1997. Hot features are dark, and cold features are bright. The lava flow can be observed in this image as the black feature, and a vapor-rich (ash-poor?) plume can be observed extending from the flow region, for approximately $150 \mathrm{~km} \mathrm{(} \mathrm{90} \mathrm{mi)} \mathrm{to} \mathrm{the} \mathrm{southeast.}$

\begin{tabular}{l}
\begin{tabular}{lllll|}
\hline CLEVELAND VOLCANO $52^{\circ} 49^{\prime} \mathrm{N}$ & $169^{\circ} 57^{\prime} \mathrm{W}$ & $5,676 \mathrm{ft}$ & $(1,730 \mathrm{~m})$ \\
MINOR ERUPTION \\
Pilot report of steam and ash cloud on May 5, 1997
\end{tabular} \\
\hline
\end{tabular}

Cleveland is a large, symmetric stratovolcano the forms the western half of Chuginadak Island-one of The Islands of The Four Mountains Group--40 km (25 mi) west of Umnak Island in the central Aleutians. The islands are remote, uninhabited, and without seismic instrumentation. The nearest settlement is Nikolski, about $50 \mathrm{~km}(\sim 30 \mathrm{mi})$ east of the volcano. Cleveland is the tallest volcano of the Group and perhaps the most active, with about a dozen reports of historical eruptive activity. Anomalous heat flux reportedly affects the summit snow cover (Sekora, 
1973). The most recent sustained eruption occurred in 1987 and produced minor lava flows as well as steam and ash emissions (Smithsonian Institution, 1987).

On May 5, 1997, the U.S. Coast Guard relayed to AVO a PIREP of a steam and ash cloud rising from Cleveland at 1600 ADT. The USCG C-130 crew took video footage to document their observations. The activity was characterized by the pilots as profuse steaming from the summit crater with intermittent, pulsing, bulbous emissions of ash. Summit snow cover was distinctly marked with patches of black (either ash or bare ground) that extended down the flank, and the plume visibly extended for about $50 \mathrm{~km}(\sim 30 \mathrm{mi})$ downwind. The activity appears similar to that reported in 1994 (Neal and others, 1995). AVO analysis of satellite imagery revealed a small hot spot. No information release was issued and AVO received no further information.

\begin{tabular}{|c|c|c|c|}
\hline AMUKTA VOLCANO & $52^{\circ} 30^{\prime} \mathrm{N}$ & $171^{\circ} 15^{\prime} \mathrm{W}$ & $3,498 \mathrm{ft} \quad(1,066 \mathrm{~m})$ \\
\hline
\end{tabular}

Amukta is a youthful stratovolcano, located $386 \mathrm{~km}$ (240 mi) southwest of Dutch Harbor, that encompasses most of uninhabited Amukta Island, westernmost of the Islands of The Four Mountains Group in the central Aleutians (Miller and others, 1998). The cone is $5.8 \mathrm{~km}$ (3.6 mi) in diameter with a $0.4-\mathrm{km}$-wide $(1,312-\mathrm{ft})$ summit crater. About a half dozen reports of eruptive activity are on record beginning in 1770, three of which occurred since the early 1980s suggesting that minor eruptive activity may be more frequent than the historical record portrays for this remote volcano. An eruption in February 1963, produced ash plumes and a lava flow that reached the sea. The last reported eruptive activity occurred in early July 1996 (Neal and McGimsey, 1997).

On March 3, 1997, Dutch Harbor air-taxi operator Tom Madsen reported seeing a small ash eruption at Amukta with the cloud barely clearing the top of the cone. No evidence of eruptive activity was detected from analysis of satellite images. The PIREP was included in AVO weekly updates of March 7 and 14. Absence of seismic instrumentation coupled with remoteness of the area requires AVO to rely mainly on PIREPs and satellite imagery for monitoring the volcanoes of the central and western Aleutians. No further information on Amukta was reported to AVO. The activity was also reported in the GVN bulletin (Smithsonian Institution, 1997a) 


\section{VOLCANIC ACTIVITY, KAMCHATKA PENINSULA, and the NORTHERN KURILE ISLANDS, RUSSIA}

Thirty historically active volcanoes on Russia's Kamchatka Peninsula pose a serious threat to aircraft in U.S. controlled air space east of Kamchatka (fig. 16). Through a formal agreement with the Institute of Volcanic Geology and Geochemistry (IVGG), AVO assists with global distribution of information about eruptions in Russia. The Kamchatkan Volcanic Eruption Response Team (KVERT) issues a weekly information release, which AVO posts to our internet website and disseminates via facsimile and email to recipients of our Alaska Volcanoes weekly updates. [Note: KVERT operations were suspended from early April to mid-July, 1997, due to funding problems.] In 1997, AVO processed information about eruptions and volcanic unrest at 4 Kamchatkan volcanoes and a report that proved to be false regarding 1 volcano in the northern Kurile Islands (fig. 16). The following accounts give times in Alaska Standard or Daylight Time (AST or ADT), Kamchatkan Standard or Daylight Time (KST or KDT) which is 21 hours ahead of Alaska time, and Coordinated Universal Time (UTC), which equals ADT $+8 \mathrm{hrs}$. and AST+9 hrs.

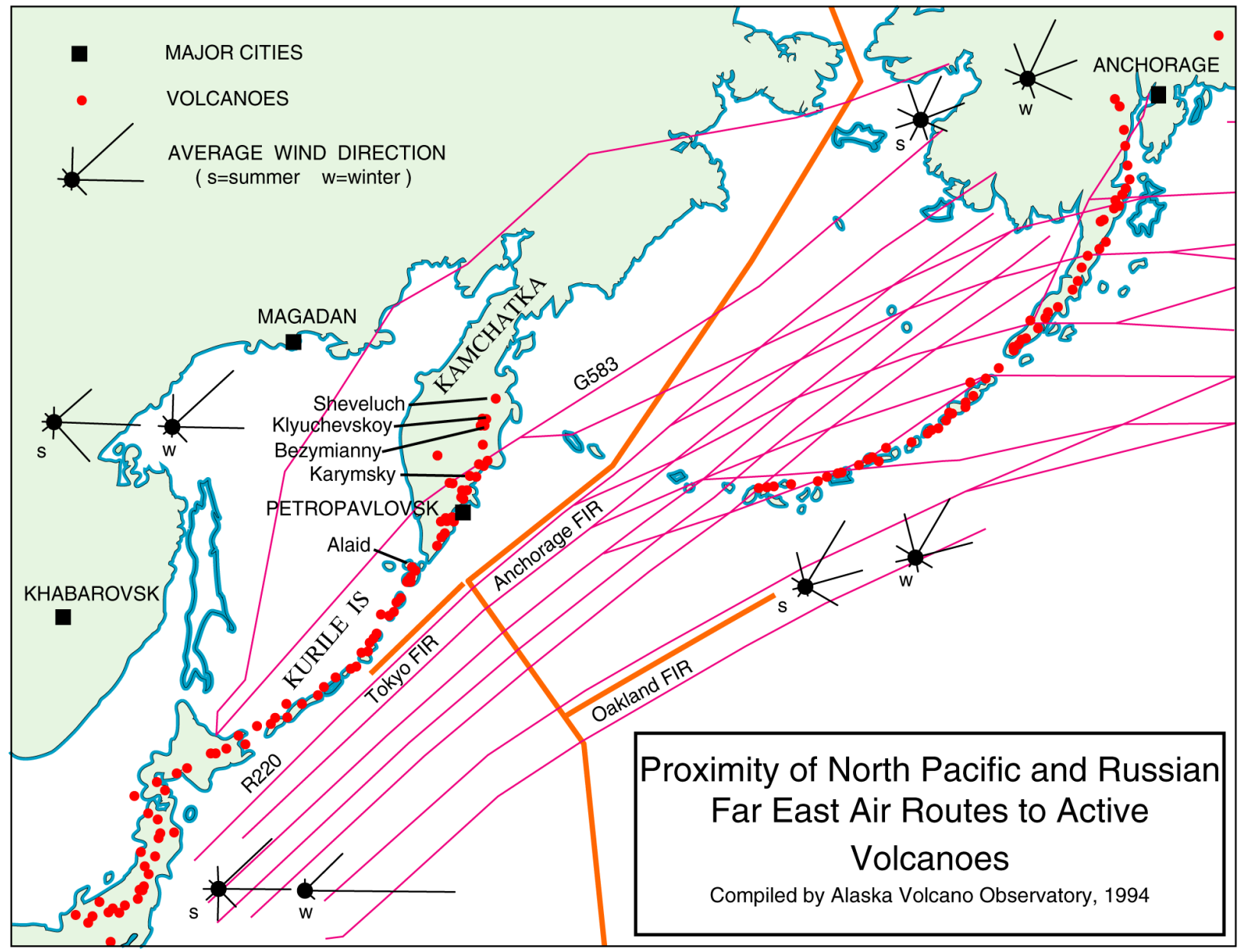

Figure 16. Location map for Sheveluch, Klyuchevskoy, Bezymianny, Karymsky, and Alaid volcanoes on Kamchatka Peninsula and northern Kurile Islands, and their proximity to North Pacific and Russian Far East air routes. 


$\begin{aligned} & \text { SHEVELUCH VOLCANO } \\ & \text { Kamchatka Peninsula, Russia }\end{aligned}$
$\begin{aligned} & \text { Dome extrusion observed on May } \\ & \text { plumes }\end{aligned}$

Extrusion of a lava dome was observed in the active crater of Sheveluch on March 8-9, 1997. Explosive emissions on March 8 sent ash and steam to 12,000 ft $(\sim 3,700 \mathrm{~m})$ above the crater and $80 \mathrm{~km}(50 \mathrm{mi})$ downwind to the north. The Level Of Concern Color Code was raised to YELLOW and returned to GREEN one week later as the activity waned. Over the next few weeks, steam and gas plumes rose up as high 5,000 ft $(\sim 1,500 \mathrm{~m})$ above the crater. The activity was reported in KVERT weekly information releases from March 9 to April 6, 1997, until suspension of KVERT operations for the next 2 months due to funding problems. Low-level gas and steam emissions occurred during the third week of July. On July 21 and 27, incandescent gas emissions rose $\sim 1,200 \mathrm{ft}(\sim 300-400 \mathrm{~m})$ above the dome and gas explosions on July 22-26 rose up to 5,000 $\mathrm{ft}(\sim 1,500 \mathrm{~m})$ above the crater, prompting KVERT to upgrade the Color Code to YELLOW. The status was returned to GREEN the following week. Low-level gas emissions up to several hundred meters above the crater characterized the volcano for the remainder of the year.

AVO closely monitored satellite imagery and disseminated eruption information to the FAA and NWS. Weekly contact was informally maintained with KVERT scientists during their 2-month suspension of operations.

$\begin{aligned} & \text { KLYUCHEVSKOY VOLCANO } \\ & \text { Kamchatka Peninsula, Russia }\end{aligned}$
$\begin{aligned} & \text { Continuation of } 1996 \text { eruption; elevated seismicity; explosive events on February 3, } 1997 \text { and } \\ & \text { March 5, } 1997\end{aligned}$

Klyuchevskoy is a classic stratovolcano and highest of the active European and Asian volcanoes. It is frequently active and the most recent significant activity prior to the ongoing eruption cycle was September 30-October 1, 1994.

Klyuchevskoy volcano began erupting in mid-November 1996 with activity continuing through 1997. Elevated seismicity and emission of gas and ash plumes up to about 24,000 ft ( 7,300 m) ASL characterized the 1996 activity (Neal and McGimsey, 1997). On January 1, 1997, the level of concern color code was GREEN and the activity consisted of daily minor gas and steam explosions which sent plumes up to about $600 \mathrm{ft}(\sim 200 \mathrm{~m})$ above the volcano. On January 8, 1997, the color code was upgraded to YELLOW as eruptive activity increased on the 7th with an ash and steam plume rising 8,000-10,000 $\mathrm{ft}(\sim 2,500$ to 3,000 $\mathrm{m})$ above the volcano and extending $20 \mathrm{~km}$ to the southeast. AVO analyzed satellite imagery of early January 8 and determined that the plume had subsided. The color code was reduced to GREEN on January 13 and seismicity remained slightly above normal with variable gas and steam plumes rising 600 to about 3,000 ft ( 200 to $900 \mathrm{~m}$ ) above the volcano. Seismicity increased during the week of January 27-February 2, with a significant rise about 9:30 am KST (2030 UTC). An explosive 
eruption began at 10:30 am KST (2130 UTC) from the central crater. By 11:30 am KST (2230 UTC) ash explosions were rising to $1,000 \mathrm{ft}(\sim 300 \mathrm{~m})$ with an ash plume extending $30-50 \mathrm{~km}$ $(\sim 18-30 \mathrm{mi})$ to the south-southeast. The activity had declined by 12:30 pm KST. The level of concern color code was reduced to GREEN on February 9, 1997 and gas and steam plumes rose up about $600 \mathrm{ft}(\sim 200 \mathrm{~m})$ above the volcano to the end of February. On February 27, the plume included minor ash and rose to 3,000 ft $(\sim 1,000 \mathrm{~m})$ above the volcano. Abruptly on March 5, at $11 \mathrm{pm} \mathrm{KST}$, an explosive eruption began from several vents in the summit crater sending ash plumes to $22,000 \mathrm{ft}$ ASL ( 2,000 $\mathrm{m}$ above the volcano) and the color code was raised to ORANGE. Pilots estimated the ash cloud at 25,000-29,000 ft ( 7,500-9,000 m) ASL, and analysis of satellite imagery by AVO determined that the ash plume extended $65-100 \mathrm{~km}$ (40-65 $\mathrm{mi})$ to the southeast. The activity level remained high for next few days with gas and steam explosions sending plumes up to 21,000 ft ( 6,500 m) ASL. AVO monitored the extent and direction of the plumes through satellite images. The color code was reduced to GREEN on March 9, and for the next five months the activity was characterized by steam and gas plumes that rose 150-1500 ft ( 50-500 m) above the crater. [Note that KVERT was not in operation April-mid July 1997, and AVO received no formal updates during that period.] When KVERT operations resumed in mid-July, seismicity at Klyuchevskoy was reported to be at background levels with fumarolic activity producing gas and steam plumes up to about $600 \mathrm{ft}(\sim 200 \mathrm{~m})$ above the crater. An ash and steam plume rose to about 2,000 ft ( $\sim 60 \mathrm{~m})$ above the crater on August 1, and increased seismicity prompted an upgrade in the color code to YELLOW on August 1. Strong volcanic earthquakes inside the crater and continued emission of gas and steam plumes occurred through the week of August 17. On August 24, the color code was reduced to GREEN following a decrease in seismicity. Throughout the remainder of 1997, the activity was characterized by gas and steam plumes rising up to about $600 \mathrm{ft}(\sim 200 \mathrm{~m})$ above the crater. Several more robust plumes attained heights of about 3,000-6,500 ft ( 1,000-2,000 m) above the crater, prompting short-lived color code upgrades to YELLOW (September 8-October 5; November 11-24). Color code YELLOW was also assigned December 1-14, 1997 when seismic tremor was recorded. The eruption continued into 1998.

\author{
BEZYMIANNY VOLCANO $\quad 55^{\circ} 58^{\prime} \mathrm{N} \quad 160^{\circ} 36^{\prime} \mathrm{E} \quad 2,800 \mathrm{~m}(9,187 \mathrm{ft})$ \\ Kamchatka Peninsula, Russia \\ Dome-collapse eruption on May 8, 1997 with ash to 6,100 m ( 20,000 ft); explosive eruption \\ December 4, 1997
}

Bezymianny Volcano emerged from a 900-1000 year period of quiescence with an explosive eruption in 1956 that culminated in the catastrophic failure of the eastern flank, producing a large debris avalanche and lateral blast, very similar to what later occurred at Mount St. Helens in 1980 (Voight and others, 1981). Since then, lava extrusion has produced a dome that periodically avalanches, generating pyroclastic flows. Over 30 eruptions have been documented since 1956, making it one of the most active volcanoes on the Kamchatka Peninsula (Simkin and Siebert, 1994). The last significant eruption was in October 1995 (McGimsey and Neal, 1996).

In early May 1997 Bezymianny volcano became restless with activity culminating on May 8 with partial collapse of the central lava dome. An ash plume was first seen by ground observers rising to about 13,000 $\mathrm{ft}(\sim 4,000 \mathrm{~m})$ ASL early on the morning of May 8. By $1 \mathrm{pm} \mathrm{KDT}$, 
continuous seismic tremor was recorded and at 2 pm KDT (0100 UTC), a short-lived but intense eruption began. Early estimates by ground observers of the ash cloud height of over 45,000 ft $(\sim 14 \mathrm{~km})$ ASL were later corrected to $20,000 \mathrm{ft}(\sim 6,100 \mathrm{~m})$ by onsite volcanologists . Satellite imagery of 8:29 pm ADT May 8 showed the ash cloud extending about $400 \mathrm{~km}$ (250 mi) eastnortheast (fig. 17). Over the next 12 hours, eruptive and seismic activity declined. Satellite imagery indicated that the volcano was obscured by clouds and no plume was visible rising through the clouds. No further activity was noted until May 15 when AVO satellite images revealed an apparent plume extending $60 \mathrm{~km}(37 \mathrm{mi})$ to the east-southeast.

Although KVERT was not officially in operation during this period, AVO contacted Russian volcanologists who provided information on the eruption. AVO scientists first detected thermal anomalies at Bezymianny on satellite images several days prior to dome collapse. At 9 pm ADT on May 8, AVO was alerted by FAA of a message received from KVERT staff about an eruption at Bezymianny. AVO responded by immediately updating the eruption hotline--a daily phone message accessed by the airline industry to get up-to-date information on eruptions--to state that Bezymianny was in Color Code RED. An AVO update was issued at 11:50 pm ADT (0750 UTC) to report the eruption. Another update was issued the following day, May 9, at 1:30 pm ADT (2130 UTC) to report the decline in activity. AVO maintained close contact with Russian volcanologists and closely monitored satellite imagery for signs of further eruptive activity. The eruption did not disrupt air traffic in the North Pacific air corridor.

When KVERT resumed operations on July 14, 1997, their weekly information releases included the status of Bezymianny for the remainder of the year. Minor fumarolic activity and normal background seismicity characterized the volcano until early December 1997. On December 2, AVO remote sensing specialists identified on satellite images a 2-pixel thermal anomaly at Bezymianny. When KVERT volcanologists were contacted they reported that seismicity was normal and no plumes were visible. AVO continued to monitor the anomaly for the next couple of days during which it increased in size and intensity (from 2 to 12 pixels). In the absence of unusual seismicity, the thermal anomaly was assumed to represent small debris avalanches off the lava dome. On December 4, at about 9:30 am AST (06:30 am KST on December 5, 1730 UTC), with no precursory seismicity, seismic activity abruptly increased signaling the onset of an explosive eruption at Bezymianny volcano (fig. 18). KVERT issued an information release through AVO at 5:15 pm AST (2:15 pm KST on December 5, 0115 UTC). Two hours later, the plume height was estimated at 20,000 ft $(\sim 6 \mathrm{~km})$ ASL with the cloud drifting $20 \mathrm{~km}(\sim 12 \mathrm{mi})$ northeast. The eruption intensified and by $3 \mathrm{pm}$ AST KVERT reported the plume height at $30,000 \mathrm{ft}(\sim 9 \mathrm{~km})$. Satellite imagery at 4:30 pm AST revealed the ash cloud stretching eastward for $250 \mathrm{~km}(\sim 150 \mathrm{mi})$ and pilots reported the cloud to heights of about 35,000 to 39,000 ft $(\sim 10,500$ to $12,000 \mathrm{~m})$. The eruption was designated Color Code RED in KVERT's next information release, issued at $11 \mathrm{pm} \mathrm{AST} \mathrm{(8} \mathrm{pm} \mathrm{KST} \mathrm{on} \mathrm{December} \mathrm{5,} 0700$ UTC). During the night, eruptive activity significantly declined and an information release issued at 2:15 pm AST on December 5 (11:15 am KST on December 6) reduced the level of concern color code from RED to YELLOW. Seismic activity could not be evaluated due to intense aftershocks from a magnitude 7.8 regional earthquake off the east coast of Kamchatka after the start of the eruption. Activity remained low and consisted of minor fumarolic and gas plumes that rose only several hundred meters above the volcano throughout the remainder or December. The level of concern color code was reduced to GREEN on December 9, 1997. 


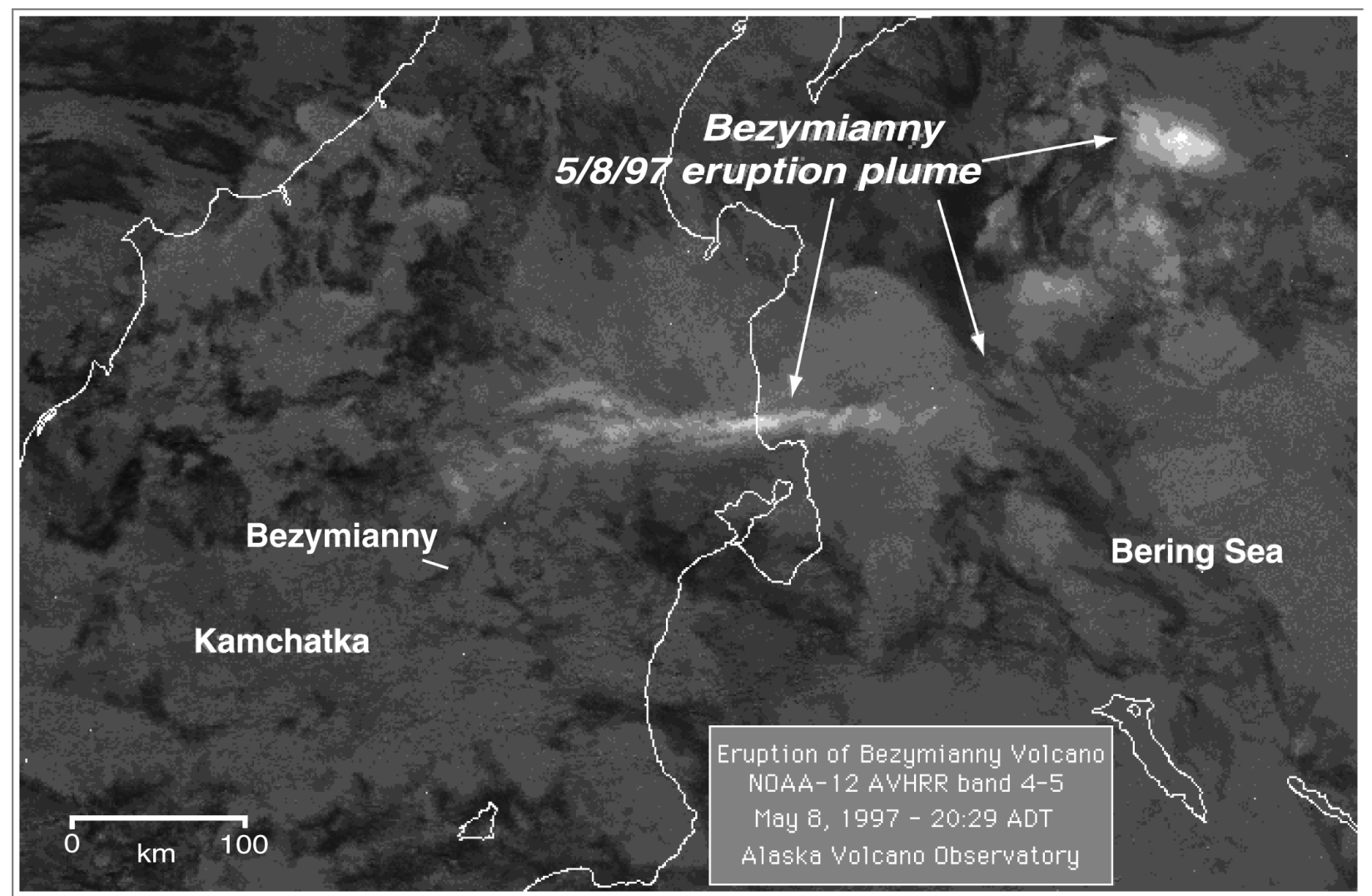

Figure 17. AVHRR band 4 minus 5 satellite image collected on May 8, 1997 (May 9 UTC). At the time of this image, the main pulse of the eruption was over and the cloud had detached from the vent and was drifting away to the north and east. The leading (NE) edge of the volcanic ash cloud is about $400 \mathrm{~km}$ (250 mi) from the vent. 


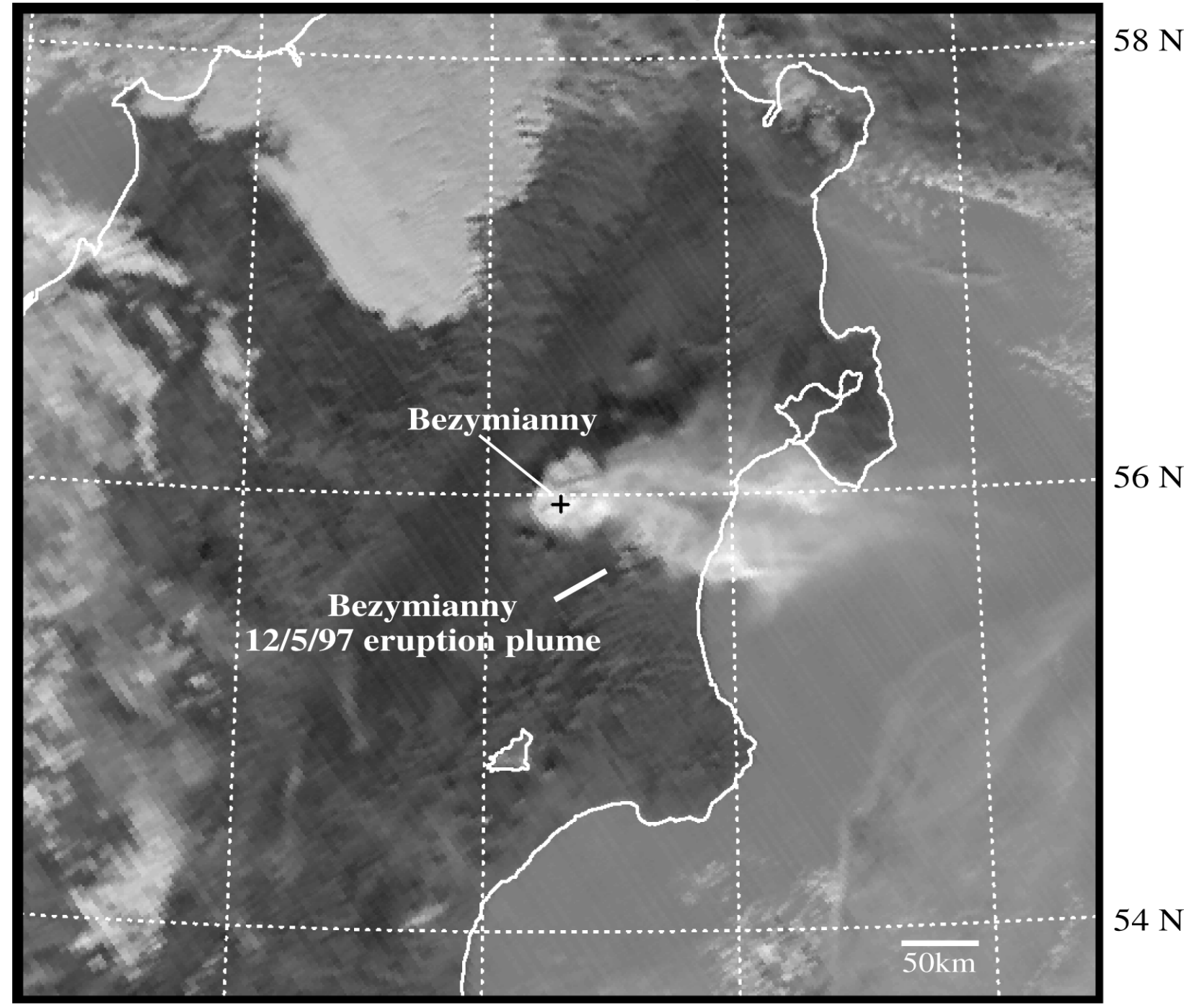

Figure 18. AVHRR band 3 satellite image collected on December 5, 1997. Features with high reflectivity are bright (e.g. ash cloud). A diffuse cloud extends to the east about $250 \mathrm{~km}(150 \mathrm{mi})$ at an altitude of about 20,000 ft $(\sim 6 \mathrm{~km})$, and a $50 \mathrm{~km}(30 \mathrm{mi})$ diameter, circular "mushroom" cloud is visible over the vent region, at a height of about 30,000 ft $(\sim 9 \mathrm{~km})$. This ash cloud was tracked in geostationary satellite imagery by AVO for about 15 hours.

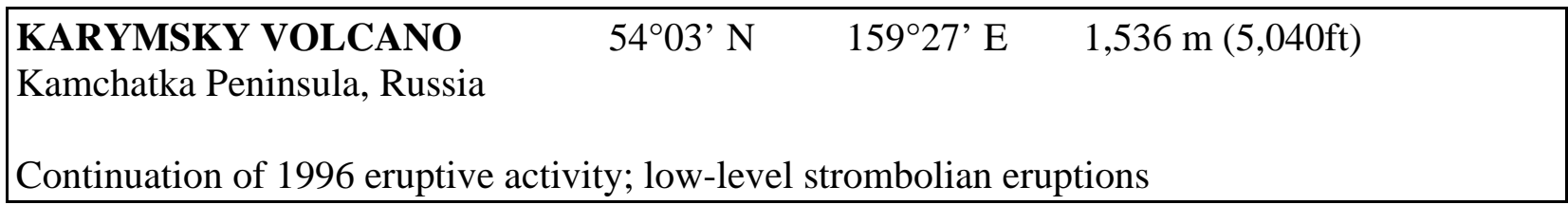

Karymsky usually issues a continuous steam plume and is the most active volcano on the Kamchatkan Peninsula with at least 26 eruptions recorded this century (fig. 19). The last eruptive period ended in 1982 (Simkin and Siebert, 1994).

Seismicity increased in mid-April, 1995, under Karymsky volcano, culminating in an explosive eruption that began on January 1, 1996, at the north end of Karymsky Lake and then shifted to 
the volcano's summit. For the remainder of 1996, periods of explosive eruptions of ash and small blocks alternated with periods of lava flow production (Neal and McGimsey, 1997). The eruption continued through 1997 with activity characterized by 50 to 100 small explosions of gas and steam per day. Seismicity has remained above background levels throughout the year and AVO analysis of satellite imagery indicates persistence of a thermal anomaly at the summit and intermittent emission of low-level ash plumes. Russian volcanologists visited Karymsky in August 1997 and documented the ongoing Strombolian eruptive activity and a new 60 -meter-wide ( $200 \mathrm{ft})$ blocky lava flow moving from the crater $350 \mathrm{~m}(\sim 1,200 \mathrm{ft})$ down the southwest flank (fig. 19). The level of concern color code remained ORANGE all year until mid-December 1997 when it was downgraded to YELLOW.

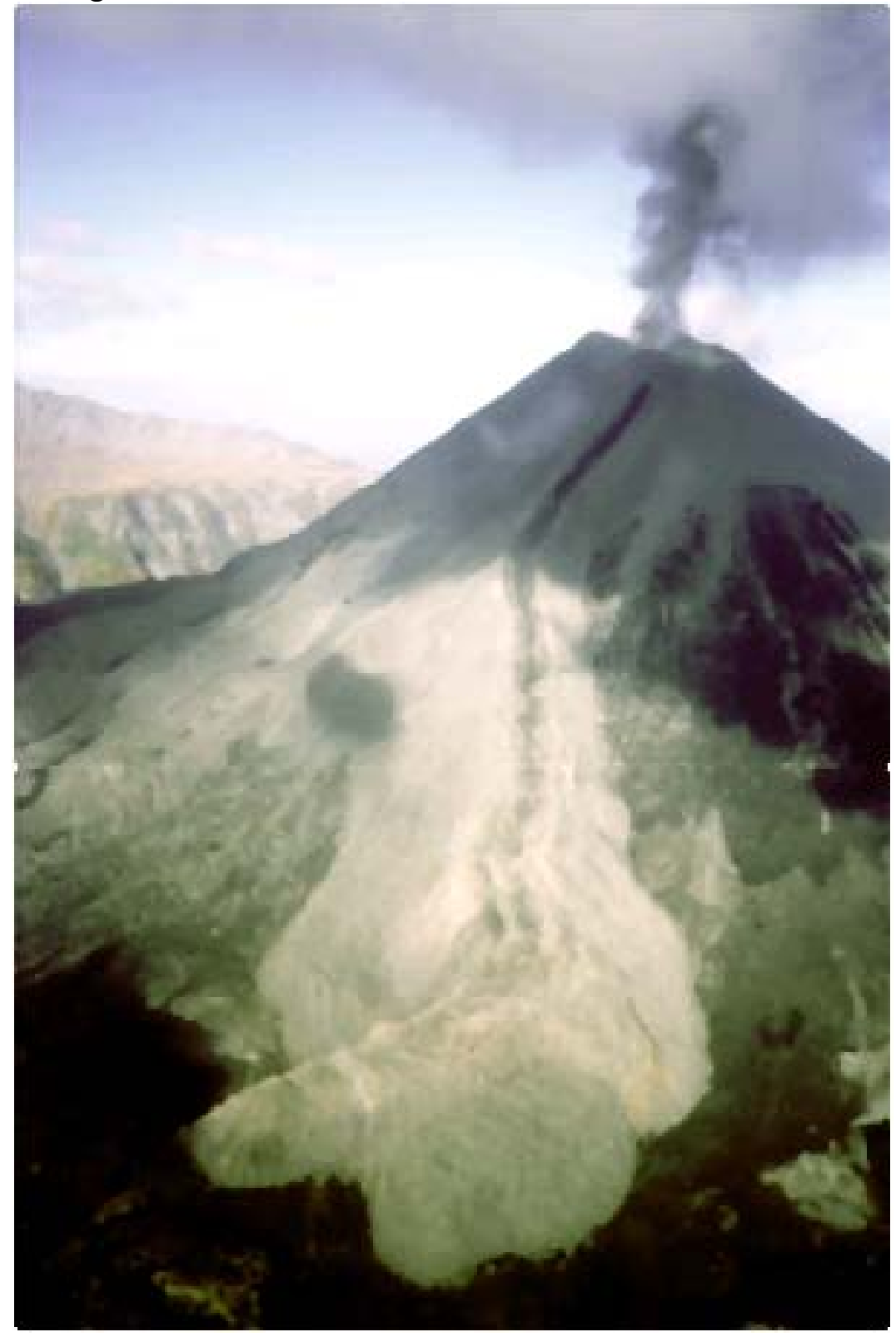

Figure 19. Blocky lava flow extending down the southwest flank of Karymsky volcano. Photo by Vladimir Kirianov, October 1996. 


$\begin{aligned} & \text { ALAID VOLCANO } \\ & \text { Northern Kurile Islands, Russia }\end{aligned}$
SUSPECT VOLCANIC ACTIVITY
Anomalous thermal feature on satellite imagery August 23, $1997 \quad 155^{\circ} 56^{\prime} \mathrm{E} \quad 2,339 \mathrm{~m}(7,672 \mathrm{ft})$

On August 23, 1997, a possible thermal anomaly was detected on satellite images of the northern Kurile Islands that corresponded to Alaid volcano. Early reports of light ashfall on the southwestern part of the Kamchatkan Peninsula were not corroborated by personal communication with residents. AVO analysis of satellite imagery over the next several days produced no evidence of ash plumes or anomalous eruptive activity. Russian volcanologist Vladimir Kirianov observed from the air on August 30 clean snow in the summit area and no sign of recent eruptive activity. The initial report prompted diversion of a commercial passenger aircraft (V. Kirianov, pers. comm.). The information was summarized in KVERT's Information Release 97-24.

Alaid volcano last erupted in December 1996 (Neal and McGimsey, 1997) 


\section{REFERENCES}

Byers, F.M., Jr., 1959, Geology of Umnak and Bogoslof Islands, Aleutian Islands, Alaska: U.S. Geological Survey Bulletin 1028-L, 369 p.

McGimsey, R.G., Neal, C.A., and Doukas, M.P., 1995, 1992 Volcanic activity in Alaska: Summary of events and response of the Alaska Volcano Observatory: U.S. Geological Survey Open-File Report 95-83, 26 p.

McGimsey, R.G., and Neal, C.A., 1996, 1995 Volcanic activity in Alaska: Summary of events and response of the Alaska Volcano Observatory: U.S. Geological Survey Open-File Report 96-738, 22 p.

Miller, T.P., McGimsey, R.G., Richter, D.H., Riehle, J.R., Nye, C.J., Yount, M.E., and Dumoulin, J.A., 1998, Catalog of the historically active volcanoes of Alaska: U.S. Geological Survey Open-File Report 98-582, 104 p.

Neal, C.A., Doukas, M.P., and McGimsey, R.G., 1995, 1994 Volcanic activity in Alaska: Summary of events and response of the Alaska Volcano Observatory: U.S. Geological Survey Open-File Report 95-271, 18 p.

Neal, C.A., McGimsey, R.G., and Doukas, M.P., 1996, 1993 Volcanic activity in Alaska: Summary of events and response of the Alaska Volcano Observatory: U.S. Geological Survey Open-File Report 96-24, 21 p.

Neal, C.A., and McGimsey, R.G., 1997, 1996 volcanic activity in Alaska and Kamchatka: Summary of events and response of the Alaska Volcano Observatory: U.S. Geological Survey Open-File Report 97-433, 34 p.

Nichols, D.R., and Yehle, L.A., 1961, Mud volcanoes in the Copper River Basin, Alaska, in Raasch, G.O., ed., Geology of the Arctic: International Symposium on Arctic Geology, $1^{\text {st }}$, Calgary, 1960, Proceedings, v. 2, p. 1063-1087.

Nye, C. J., 1991, Mount Wrangell, in: Volcanoes of North America, Wood, C.A., and Kienle, J., eds., Cambridge University Press, p. 88-89.

Richter, D.H., Rosenkrans, D.S., and Steigerwald, M.J., 1995, Guide to the volcanoes of the western Wrangell Mountains, Alaska: U.S. Geological Survey Bulletin 2072, 31 p.

Richter, D.H., Symonds, R.B., Rosenkrans, D.S., McGimsey, R.G., Evans, W.C., and Poreda, R.J., 1998, Report on the 1997 activity of Shrub mud volcano, Wrangell-St. Elias National Park and Preserve, South-central Alaska: U.S. Geological Survey Open-File Report 98-128, 13 p.

Sekora, P., 1973, Aleutian Island National Wildlife Refuge wilderness report; preliminary draft: U.S. Fish and Wildlife Service, 409 p. 
Simkin, T., and Siebert, L., 1994, Volcanoes of the world, Tucson, Arizona, Geoscience Press, Inc., 349 p.

Smithsonian Institution, 1987, Global Volcanism Network Bulletin, v. 12, no. 6.

Smithsonian Institution, 1997a, Global Volcanism Network Bulletin, v. 22, no. 9.

Smithsonian Institution, 1997b, Global Volcanism Network Bulletin, v. 22, no. 11.

Smithsonian Institution, 1997c, Global Volcanism Network Bulletin, v. 22, nos. 1-4.

Voight, B., Glicken, H., Janda, R.J., and Douglass, P.M., 1981, Catastrophic rockslide avalanche of May 18, in Lipman, P.W., and Mullineaux, D.R., eds., The 1980 eruptions of Mount St. Helens, Washington: U.S. Geological Survey Professional Paper 1250, p. 347-378.

Wood, C.A., and Kienle, J., 1990, Volcanoes of North America, Cambridge University Press, New York, 354 p.

\section{ACKNOWLEDGMENTS}

Don Richter and Seth Moran improved the report with critical reviews. Vladimir Kirianov reviewed the section on Russian volcanoes. Rusty Brown, Linda Harris, and Devon Harbke helped produce some of the figures. Dave Schneider, Ken Dean, Jon Dehn, and Pavel Izbekov provided satellite imagery. 
Table 1. Summary of 1997 VOLCANIC ACTIVITY in Alaska, including actual eruptions, possible eruptions, and unusual increases in fumarolic activity. Location of volcanoes shown in Figure 1.

\begin{tabular}{|c|c|c|}
\hline Volcano & Date of Activity & Type of Activity \\
\hline Shrub Mud Volcano & spring 1997 ongoing & $\begin{array}{l}\text { voluminous, energetic ejection of } \\
\text { warm saline mud and } \mathrm{CO}_{2} \text { from } \\
\text { multiple vents; } \mathrm{CO}_{2} \text { hazard } \\
\text { recognized }\end{array}$ \\
\hline Iliamna Volcano & July 1996 -March 1997 & anomalous seismic swarm \\
\hline Chiginagak Volcano & October 1997 & $\begin{array}{l}\text { Development of new fumarole } \\
\text { field with significantly increased } \\
\text { steaming }\end{array}$ \\
\hline Pavlof Volcano & September 1996 -January 1997 & $\begin{array}{l}\text { conclusion of strombolian } \\
\text { eruption }\end{array}$ \\
\hline Shishaldin Volcano & June 2, 1997 & $\begin{array}{l}\text { NWS observer in Cold Bay } \\
\text { reports steam and ash plume } \\
\text { rising } 1,500 \mathrm{ft}(\sim 450 \mathrm{~m})\end{array}$ \\
\hline Okmok Volcano & February 13,1997 to May $1997 *$ & $\begin{array}{l}\text { strombolian eruption from } \\
\text { intracaldera Cone A; extensive } \\
\text { lava flow, and intermittent ash } \\
\text { clouds from } 10,000 \text { to } 30,000 \mathrm{ft} \\
(\sim 3,000-9,000 \mathrm{~m}) \text { ASL }\end{array}$ \\
\hline Cleveland Volcano & May 5, 1997 & $\begin{array}{l}\text { USCG pilot report of steam and } \\
\text { ash cloud, extending } 50 \mathrm{~km}(\sim 30 \\
\text { mi) downwind, verified by } \\
\text { satellite imagery }\end{array}$ \\
\hline
\end{tabular}

* end of eruptive activity not well documented 
Table 2. Summary of SUSPECT VOLCANIC ACTIVITY (SVA) in 1997. SVA is defined as a report of eruption or possible eruption that is found to be normal fumarolic activity or non-volcanic phenomena, such as weather related. Location of volcanoes shown in Figure 1.

\begin{tabular}{lll}
\hline Volcano & Date of Activity & Type of Activity
\end{tabular}

Wrangell Volcano

Mt. Sanford

Katmai group

Martin/Mageik

Snowy/Kukak

Amukta Volcano
February 19, 1997

December 11, 1997

March 3, 1997

June 3, 1997 and June 24, 1997

September 30, 1997

June 3, 1997 steam plumes from summit large steam cloud rising from southwest face; avalanche generated

anomalous steamplume rising to $5,000 \mathrm{ft}(\sim 1,500 \mathrm{~m})$ from Martin or Mageik

ground observer and pilots report large steam plume from Martin

USCG pilots report steaming fumarole vents and discolored snow pilot reports minor ash emission

Table 3. Summary of RUSSIAN VOLCANIC ACTIVITY on Kamchatka Peninsula and northern Kurile Islands, 1997. Location of volcanoes shown in Figure 16.

\begin{tabular}{|c|c|c|}
\hline Volcano & Date of Activity & Type of Activity \\
\hline Sheveluch & May 8-9, 1997 & $\begin{array}{l}\text { dome extrusion; ash to } 12,000 \mathrm{ft} \\
(\sim 4,000 \mathrm{~m}) \text { above crater }\end{array}$ \\
\hline Klyuchevskoy & February 3, 1997; March 5, 1997 & $\begin{array}{l}\text { continuation of } 1996 \text { eruption; } \\
\text { explosive events }\end{array}$ \\
\hline Bezymianny & $\begin{array}{l}\text { May 8, 1997; December 14, } \\
1997\end{array}$ & $\begin{array}{l}\text { dome collapse with ash to } \\
20,000 \mathrm{ft}(\sim 6,100 \mathrm{~m}) \text { ASL; } \\
\text { explosive eruption }\end{array}$ \\
\hline Karymsky & 1997 & $\begin{array}{l}\text { continuation of } 1996 \text { strombolian } \\
\text { eruption }\end{array}$ \\
\hline Alaid & August 23, 1997 & $\begin{array}{l}\text { anomalous thermal feature on } \\
\text { satellite imagery that proved to } \\
\text { be non-volcanic }\end{array}$ \\
\hline
\end{tabular}


Table 4. Level of Concern Color Code for volcanic activity.

\section{LEVEL OF CONCERN COLOR CODE}

To more concisely describe our level of concern about possible eruptive acitivity at Alaska volcanoes, the Alaska Volcano Observatory has developed a color-coded classification system. Definitions of the colors reflect AVOs interpretations of the behavior of the voleano. Definitions are listed below followed by general descriptions of typical activity associated with each color

GREEN

No eruption anticipated.

Volcano is in quiet, "dormant" state.

YELLOW An eruption is possible in the next few weeks and may occur with little or no additional warning

Small earthquakes detected locally and (or) increased levels of volcanic gas emissions.

ORANGE

Explosive eruption is possible within a few days and may occur with little or no warning. Ash plume(s) not expected to reach 25,000 feet above sea level.

Increased numbers of local earthquakes. Extrusion of a lave dome or lava flows (non-explosive eruption) may be occurring.

RED

Major explosive eruption expected within 24 hours. Large ash plume(s) expected to reach at least 25,000 feet above sea level.

Strong earthquake activity detected even at distant monitoring

stations. Explosive eruption may be in progress. 


\section{GLOSSARY OF SELECTED TERMS}

$\underline{A D T:}$

acronym for "Alaska Daylight Time"

ASL:

acronym for "above sea level"

$\underline{A V O:}$

acronym for "Alaska Volcano Observatory"

$\underline{A V H R R:}$

acronym for "Advanced Very High Resolution Radiometer"; AVHRR provides one form of satellite imagery

$\underline{\text { ash: }}$

fine fragments (less than 2 millimeters across) of lava or rock formed in an explosive volcanic eruption

basalt: general term for dark-colored mafic igneous rock, usually extrusive, containing less than 52 weight percent silica

$\underline{\text { bomb: }}$

boulder-size chunk of partly solidified lava explosively ejected from a volcano

caldera:

a large, roughly circular depression usually caused by volcanic collapse or explosion

cinder cone:

small, steep-sided conical hill built mainly of cinder, spatter, and volcanic bombs

FAA:

acronym for "Federal Aviation Administration"

fallout:

a general term for debris which falls to the earth from an eruption cloud

fault:

a fracture or zone of fractures along which there has been displacement of the sides relative to one another

fissure:

a roughly linear or sinuous crack or opening on a volcano; a type of vent which commonly produces lava fountains and flows

fumarole:

a small opening or vent from which hot gases are emitted

$\underline{G V N:}$

acronym for "Global Volcanism Network"

Holocene:

geologic epoch extending from the last 10,000 years to present

incandescent:

glowing red or orange due to high temperature

intracaldera:

refers to something within the caldera 
$\underline{I V G G:}$

$\underline{K D T:}$

KVERT:

lava:

magma:

NOAA:

NOPAC:

NOTAM:

NWS:

phreatic activity:

phreatic ash:

PIREP:

pixel: acronym for Russian "Institute of Volcanic Geology and Geochemistry"

acronym for "Kamchatkan Daylight Time", which $=$ ADT +21 hrs.

acronym for Russian "Kamchatkan Volcano Eruption Response Team"

when molten material reaches the earth's surface, it is called lava

molten material below the surface of the earth

acronym for "National Oceanic and Atmospheric Administration"

acronym for "North Pacific Air Corridor"

acronym for "Notice to Airmen", a notice containing information [not known sufficiently in advance to publicize by other means] concerning the establishment, condition, or change in any component [facility, service, or procedure of, or hazard in the National Airspace System] the timely knowledge of which is essential to personnel concerned with flight operations

acronym for "National Weather Service"

an explosive eruption caused by the sudden heating of ground water as it comes in contact with hot volcanic rock or magma

fine fragments of volcanic rock expelled during phreatic activity; this ash is usually derived from existing rock and not from new magma acronym for "Pilot Weather Report - A report of meteorological phenomena encountered by aircraft in flight

"picture element", the smallest discrete rectangular area of an image or picture on either a screen or stored in memory. The greater the number of pixels per inch the greater the resolution. Each pixel in a monochrome image has its own brightness.

regional earthquake: earthquake generated by fracture or slippage along a fault; not caused by volcanic activity

RFE: $\quad$ acronym for "Russian Far East"

$\underline{S A R}: \quad \quad$ acronym for "Synthetic Aperture Radar"

satellite cone: a subsidiary volcanic vent located on the flank of a larger volcano

seismic swarm: $\quad$ a flurry of closely spaced earthquakes or other ground shaking 
activity; often precedes an eruption

shield volcano: $\quad$ a broad, gently sloping volcano usually composed of fluid, lava flows of basalt composition (e.g. Mauna Loa)

stratovolcano: (also called a stratocone or composite cone) a steep-sided volcano, usually conical in shape, built of lava flows and fragmental deposits from explosive eruptions

strombolian: $\quad$ type of volcanic eruption characterized by intermittent bursts of fluid lava, usually basalt, from a vent or crater

subplinian:

style of explosive eruptions characterized by vertical eruption columns and widespread dispersal of tephra

SVA: acronym for "suspected volcanic activity"

tephra: $\quad$ a general term covering all fragmental material expelled from a volcano (ash, bombs, cinders, etc.)

USCG: $\quad$ acronym for "U.S. Coast Guard"

$\underline{U S G S:} \quad$ acronym for "U.S. Geological Survey"

UTC: $\quad$ acronym for "Coordinated Universal Time"; same as Greenwich Mean Time (GMT)

vent: an opening in the earth's surface through which magma erupts or volcanic gasses are emitted

volcano-tectonic earthquakes:

earthquakes generated within a volcano from brittle rock failure resulting from strain induced by volcanic processes

\section{FOR PHOTOGRAPHIC IMAGES OF VOLCANOES IN THIS REPORT:}

Duplicate 35-mm slides and prints of some volcanoes discussed in this report are available from: 
The Photo Library

U.S. Geological Survey

MS 914 Box 25046 Federal Center

Denver, CO 80225-0046

303-236-1010

\section{OTHER MULTI-MEDIA PRODUCTS OF INTEREST:}

PHOTOGRAPHS OF THE 1989-90 ERUPTIONS OF REDOUBT VOLCANO, ALASKA, USGS Open-file Report 96-689, 20 slides, 10 p. text and glossary, by A.L. Roach, C.A. Neal, and R.G. McGimsey.

PHOTOGRAPHS OF THE 1992 ERUPTIONS OF CRATER PEAK, SPURR VOLCANO, ALASKA, USGS Open-file Report 93-707, 20 slides, 8 p. text and glossary, by Christina A. Neal, Robert G. McGimsey, Michael P. Doukas, and Inyo Ellerseick, 1993. 20-slide set illustrating aspects of the 1992 eruptions. Includes captions and glossary.

VOLCANOES OF THE WRANGELL MOUNTAINS AND COOK INLET REGION, ALASKA - SELECTED PHOTOGRAPHS, U.S. Geological Survey, Digital Data Series 96-039, 1996, CD-ROM.

VOLCANOES OF THE ALASKA PENINSULA AND ALEUTIAN ISLANDS, ALASKA SELECTED PHOTOGRAPHS, U.S. Geological Survey, Digital Data Series 96-040, 1996, CDROM.

The publications listed above are available from:

U.S. Geological Survey ESIC-Open-File Report Section

Box 25286, MS 517

Denver, CO 80225-0046

303-236-7476

VIDEO OF THE AUGUST 18,1992, ERUPTION OF CRATER PEAK VENT ON SPURR VOLCANO, ALASKA", by Robert G. McGimsey and Joseph M. Dorava, 1994, USGS OpenFile Report 94-614. This 25-minute, narrated video presents dramatic scenes of the second of three 1992 eruptions of Crater Peak, a satellite vent on Spurr volcano, Alaska. Favorable weather conditions permitted scientists from the Alaska Volcano Observatory to photograph the eruption from a fixed-wing aircraft flying as close as $2 \mathrm{~km}$ to the vent. The video includes close-up views of the roiling, 18-kilometer-high eruption column, shockwaves emanating from the column base, ash clouds from pyroclastic flows on the southeast flank, and ash fallout downwind.

10 YEARS OF VOLCANIC ACTIVITY IN ALASKA: 1983 TO 1992: A VIDEO", by Michael P. Doukas, Robert G. McGimsey, and Joseph M. Dorava, 1995, USGS Open-File Report 95-61. This 28-minute video presents eruption images from eight Alaskan volcanoes during the ten-year period: Veniaminof (1983-84), Augustine (1986), Redoubt (1989-90), Akutan (1991), Bogoslof 
(1992), Westdahl (1992), Spurr (1992), and Seguam (1992). Classic volcanic phenomena are documented, including meltwater lakes formed when lava flows advanced into an ice- filled caldera (Veniaminof), nighttime views of explosive strombolian activity (Veniaminof), pyroclastic flows descending steep flanks during plinian- and peleean- style eruptions (Augustine), hawaiian-style lava fountaining through glacial ice (Westdahl), island building in the Aleutians (Bogoslof), shock waves and close-up views of a roiling, sub-plinian eruption column rising more than 18 kilometers (Mount Spurr volcano-Crater Peak vent).

The videotapes are available from:

U.S. Geological Survey

ESIC-Open-File Report Section

Box 25286, MS 517

Denver, CO 80225-0046

303-236-7476
AND KAKM Video

ATTN: Gilbert Sanchez

3877 University Drive

Anchorage, AK 99508

Phone (907) 563-7070

US or Canada 1-800-684-3368

FAX (907) 273-9192

email: kakm_video@kakm.pbs.org 